\title{
Economic crisis and the demise of a popular contractual form: Building \& Loans in the 1930s
}

\author{
Sebastian Fleitas ${ }^{\mathrm{a}}$, Price Fishback ${ }^{\mathrm{b}}$, Kenneth Snowden ${ }^{\mathrm{c}, *}$ \\ a Economics Department, University of Leuven, Belgium \\ ${ }^{\mathrm{b}}$ Economics Department, University of Arizona, and NBER Research Associate, United States \\ ${ }^{\mathrm{c}}$ Economics Department, University of North Carolina at Greensboro, and NBER Research Associate, United States
}

\section{A R T I C L E I N F O}

\section{Article history:}

Received 7 August 2016

Revised 9 August 2017

Accepted 12 August 2017

Available online $\mathrm{xxx}$

\section{Keywords:}

Mortgage

Great Depression

Savings and loan

Housing crisis

\begin{abstract}
A B S T R A C T
Before the 1930s Building and Loan Associations (B\&Ls) were the leading residential mortgage leaders in the U.S. When severely distressed during the housing crisis of the 1930s, B\&Ls frequently took years to liquidate. These delays in resolution resulted from the unique B\&L contract that encouraged borrowing members to prolong dissolution and gave them shared control over the timing of liquidation. We estimate a hazard model of dissolution using a new dataset of New Jersey B\&Ls and find that the probability of liquidation rose $37 \%$ when the share of non-borrowing members rose above two-thirds. The severe restriction on liquidity suffered by non-borrowers was instrumental to the rapid transition from the traditional B\&L to the modern Savings \& Loan industry during the 1930s housing crisis.
\end{abstract}

(c) 2017 Elsevier Inc. All rights reserved.

\section{Introduction}

Severe disruptions in the housing market associated with the Great Recession of 2007 have prompted a broad re-evaluation of the nation's residential mortgage lending channels. A similar reexamination during the devastating housing crisis of the 1930s led to a fundamental restructuring of the contracts, intermediaries and market structures that were used to fund residential mortgages. ${ }^{1}$ That transformation brought "federalization" in the form of an emergency mortgage refinancing program, a mortgage discount bank, a mortgage loan insurance program and a secondary mort-

\footnotetext{
We are very grateful for the comments and suggestions from Charles Calomiris, Joshua Hausman, Kris Mitchener, Robert Margo, Dave Ribar, Jonathan Rose, Tiemen Woutersen and participants at sessions on the paper at the World Congress of Cliometrics in 2013 and the NBER-DAE Summer Institute in 2015. Fishback and Snowden acknowledge support from the National Science Foundation (Grant SES1061927). Any opinions expressed here do not reflect the attitude of the National Science Foundation.

* Corresponding author at: Economics Department, University of North Carolina, Greensboro, United States.

E-mail addresses: sebastian.fleitas@kuleuven.be (S. Fleitas),

fishback@email.arizona.edu (P. Fishback), snowden@uncg.edu (K. Snowden).

1 Housing starts in the U.S. peaked in in 1925 at 937,000, then fell to 509,000 in 1929 and to 93,000 in 1933 . Meanwhile the nonfarm foreclosure rate quadrupled between 1926 and 1933 and remained at elevated levels until 1940. By the later date the real stock of home mortgage debt remained 15\% below its 1932 peak. Data on housing starts and the stock of home mortgage debt was compiled from Snowden (2006), 4-481 to 4-482 and 4-526 to 4-527 and deflated by the CPI $1967=100$. See Wheelock (2008) for foreclosure rates.
}

gage market facility. ${ }^{2}$ This paper examines the forces that shaped a less familiar element of change that was equally far-reachingthe transformation of the traditional Building \& Loan sector into the modern Saving \& Loan industry. By 1930 the B\&L industry had become the nation's most important institutional source of home mortgage loans due to the success of its unique, equity-based contractual arrangement, through which saving and borrowing members shared local lending risk and organizational control. This mutual lending structure foundered badly during the 1930s housing crisis, however, and by the 1940s had been reduced to a small corner of the nation's financial landscape. We show in this paper that the modern S\&L gained prominence during the housing crisis of the 1930s, while B\&Ls became marginalized, because the latter lost favor among the saving public after it was shown to impose costly illiquidity on its non-borrowing members during the housing crisis.

The key contractual element of the pre-1930 B\&L was the Share Accumulation Contract (SAC) that members used to purchase equity in the association in monthly installments. These investments offered non-borrowing members a disciplined savings plan that yielded attractive returns relative to the alternatives available at that time. The monthly contributions to SAC accounts by borrowing members, on the other hand, served as sinking funds with

\footnotetext{
2 The Federal Home Loan Bank System's discount facility was created in 1932 the Home Owner's Loan Corporation emergency refinancing program in 1933, the Federal Housing Administration's mortgage loan insurance program in 1934 and the Federal National Mortgage Association's secondary mortgage market facility in 1938.
} 
which they paid off their loans. Because all members invested in SAC contracts, B\&Ls were mutually-owned intermediaries in which borrowers and non-borrowers shared the risks and rewards on their association's mortgage portfolio. For this reason, the SAC contracts were specifically designed both to fund and to repay long-term, illiquid loans. Within the earliest "terminating" associations popular in the 1830 s, for example, non-borrowing members were required to remain in the association until the shares of all members had matured and all loans had been repaid. Innovations within the B\&L industry over the next century provided greater liquidity for non-borrowers by embedding SAC contracts into a variety of "plans" that apportioned profits and losses as some members withdrew and others joined. Within these "serial" and "permanent plan" associations, members still had to provide 30-day written notification before withdrawing and then pay penalties for leaving the association "early." Withdrawal policies became even more liberal in the 1920s as a rapid expansion of B\&Ls provided associations with steady inflows of new investments that permitted them to suspend withdrawal notifications and penalties.

These relaxed withdrawal policies were quickly undone as the Depression and the housing crisis gained momentum in the early 1930 s. $^{3}$ As repayments on outstanding loans and the flow of new members fell dramatically, B\&Ls that were no longer able to accommodate withdrawal requests could, under their bylaws, postpone withdrawals indefinitely. Thousands of associations did so and became "frozen" associations that operated for years even though they attracted no new members, made no new loans and held large quantities of foreclosed real estate as they waited for mortgages that were still in good standing to be paid off (Snowden, 2003). ${ }^{4}$ The crisis clarified to all B\&L members that their SAC accounts were not deposits and left non-borrowing members with only three options. First, they could apply to withdraw their funds, but doing so could take years after B\&Ls implemented rotation systems in which a set dollar amount of net earnings was paid each month to each withdrawing member until all their claims were satisfied (Kendall 1962, 76-7). Second, non-borrowers in larger cities also had the option of selling B\&L shares in informal secondary markets that appeared during the 1930s-although withdrawal by means of a curb sale generated a deep discount relative to the book value of the shares (Rose 2014; Kendall, 1962).

In this paper, we focus on a third possible response. As owners of their B\&L, non-borrowing members could press their frozen association to liquidate voluntarily and immediately. It is here that the contractual structure of the traditional B\&L created a conflict between borrowing and non-borrowing members. Under the terms of the SAC loan contract, borrowing members who were in good standing had strong incentives to oppose liquidation of their B\&L until their loans had been paid off. Non-borrowing members, on the other hand, generally favored more rapid resolution. B\&L contracts, and the case law that interpreted them, favored the borrowers in this conflict. The voluntary liquidation of a B\&L required the approval of two-thirds of the members-with each member in good standing having one vote. To see how this voting requirement influenced the timing of B\&L liquidations, we have collected and digitized a new panel dataset with time-varying information on the membership and balance sheets of all (more than 1500)

\footnotetext{
3 During the 1930s foreclosures spiked because of a 30 percent decrease in per capita income, a $25 \%$ decrease in the nominal value of housing, and deflation that raised the real cost of repaying loans.

4 Snowden $(2003,187-9)$ shows that the combined numbers of B\&Ls and S\&Ls fell from 12,342 to 8,318 between 1929 and 1939. Another 2,000 small associations exited the industry by 1944 . The long duration of B\&L curtailment is also reflected by the share of assets held in real estate which grew from 3 percent in 1929 to $20 \%$ in 1935 and remained at 12 percent as late as 1939.
}

B\&Ls that operated in New Jersey in the 1930s. ${ }^{5}$ Estimates from a semi-parametric Cox survival model show that the probability of liquidation rose $37 \%$ when the share of non-borrowing members rose above the two-thirds required for voluntary dissolution. This translates into a typical delay of about one year in the exit of a failing B\&L.

Delayed liquidation was a well-understood feature of the B\&L landscape throughout the 1930s (Snowden, 2003). The New Jersey case illustrates why. Between 1930 and 1935, the real estate share of assets for New Jersey B\&Ls rose from $4 \%$ to $24 \%$, a level of distress that would have led to insolvency and liquidation in other types of real estate lenders. Yet, by 1935 only 41 of 1565 New Jersey B\&Ls had closed. Another 90 associations exited between 1935 and 1938, but even by then most of the remaining 1434 B\&Ls in operation were badly distressed with an average real estate share of assets above 40\%. Between 1938 and 1940, 440 of these associations finally closed, followed by another 485 between 1940 and 1945. By the later date only 509 Building (or Savings) and Loan associations were operating in the state. ${ }^{6}$ B\&L liquidations in the 1930s took so long to complete that New Jersey, along with several other states, undertook special "Community Programs" as late as 1940 to rehabilitate the mortgage market in major "B\&L cities." 7

B\&L contracts were intentionally designed to fund long-term residential investment. The bylaws of these associations, and the case law that interpreted them, preserved this function even under the severe distress of the 1930s by suspending withdrawals and delaying liquidation. The extra time provided borrowing members an opportunity to finish repaying their loans so that foreclosures were avoided, B\&Ls dumped fewer foreclosed homes into weak housing markets, and downward pressure on local housing prices was relieved. These benefits came at substantial cost, however, to the non-borrowing B\&L members who could not withdraw their assets at book value and had to wait to obtain the liquidation value of the assets. These delays forced nonborrowers to sacrifice liquidity and to hold for extended time periods ownership claims on portfolios of poorly performing loans and foreclosed real estate. The associated costs were large enough that non-borrowing savers quickly abandoned B\&L investment and moved to a new "Savings \& Loan" contract that provided, with the support of new federal regulatory structures, a more reliably liquid investment than the traditional B\&L. The transition from B\&L to S\&L during the 1930s, therefore, offers an important example of how a contractually-delayed resolution mechanism generated institutional change during our last great mortgage crisis.

\footnotetext{
${ }^{5}$ We focus on New Jersey because it is the only state where the regulator consistently reported the number of borrowing and non-borrowing members and balance sheet information for each B\&L for each year in the 1930s.

${ }^{6}$ Information on the New Jersey B\&Ls is from the sample we constructed from New Jersey state reports, and the number of New Jersey banks come from New Jersey fared better than the nation as a whole as the U.S. number of B\&Ls and Savings and Loans declined $12.8 \%$ between 1930 and 1935 and the number of commercial banks declined 39\% between 1930 and the trough in 1933 (U.S. Bureau of Census, 1975, series X834 and series X580). Nationwide, the number of B\&Ls and Savings and Loans fell by 12.8 percent. In comparison, $27 \%$ of commercial banks and $15 \%$ of U.S. life insurance companies were eliminated nationwide between 1930 and $1933 / 34$.The national figures are from the changes in the number of insurance companies and commercial banks come from series X834 and X580 from U.S. Bureau of the Census (1975).

7 The community programs of the late 1930s are described in the Eighth (107$10,1940)$ and Ninth $(120-4,1941)$ Annual Reports of the Federal Home Loan Bank Board. The cities that were affected were New Orleans, Altoona, Philadelphia, Chicago, Milwaukee, Newark and Patterson. These programs benefitted from the support provided by the newly-created Federal Savings \& Loan Insurance Company,
} 


\section{The contractual and legal basis of delayed resolution in Building \& Loans}

Although B\&Ls were the nation's most important institutional source of home mortgages between 1880 and 1930, only recently have they received much attention in the historical literature investigating the early development of the residential mortgage market and its role in the 1930s crisis. B\&Ls were local, cooperative institutions that specialized in residential mortgage lending. The first B\&L appeared in the U.S. in the 1830s. By 1929 the 12,000 institutions operating in the U.S. claimed more than 12 million members and operated in every state and region, and in cities of all sizes. ${ }^{8}$ B\&Ls grew especially rapidly in number and importance during the home building boom of the 1920s and ended up financing 4.2 million of the 7 million homes built during that decade. By 1930 they claimed $48 \%$ of the mortgage debt held by institutional lenders on the nation's 1 to 4 family homes. ${ }^{9}$

Three features of the B\&Ls accounted for its popularity on the eve of the depression. First, the traditional B\&L mortgage was the only home loan available before 1930 that offered borrowers longterm, amortized mortgages. ${ }^{10}$ Second, B\&Ls offered non-borrowing members higher returns than the savings accounts offered by commercial and savings banks. ${ }^{11}$ Finally, B\&Ls proved to be a nimble and elastic source of mortgage finance as they faced lower barriers to entry than depository institutions and could organize even on a small scale wherever local demands and supplies of mortgage funds were sufficient. ${ }^{12}$

The rapid expansion of the B\&L industry came to a halt during the crisis of the 1930s when it took the industry more than a decade to resolve thousands of frozen B\&L associations. There are four features of the B\&L contractual structure and case law that explain why and how distress within the traditional B\&L association took so long to resolve. B\&Ls were owned by the borrowing and non-borrowing members; non-borrowing members had limited withdrawal privileges; closure of the B\&Ls required a vote of the members; and borrowing members had incentives to delay closure.

\footnotetext{
8 Bodfish (1931, p. 136) Housing Statistics Handbook, 1948, p. 87, 114. Richard Ely emphasized their importance in his forward to the 1920 U.S. Census Report Mortgages on Homes by observing that "[t]he American method of acquiring a home is to buy the site, gradually pay for it, then to mortgage it through a building and loan or otherwise, to construct the home with the aid of the mortgage and gradually to extinguish the mortgage." Individuals held nearly $40 \%$ of home mortgage debt as late as 1930. See also Bodfish, 1931, p. 138; Housing Statistics Handbook, 1948, p. 5, 60.

${ }^{9}$ Housing Statistics Handbook, 1948, p. 114. Individuals held $40 \%$ of home mortgage debt as late as 1930 .

${ }^{10}$ Before 1930 most other lenders offered homeowners interest-only, balloon loans for no more than $50 \%$ of the property's value and with maturities no longer than five years. Loans with these short maturities had to be renewed one or more times before they could be paid off and each renewal involved additional costs and risks.

11 The modal rate of earnings on book values of B\&L shares in New Jersey in 1928, for example, was $7-8 \%$ per annum. Members who paid penalties for withdrawing shares earlier than scheduled still earned six percent or higher on B\&L investments after holding the shares for five years. At the same time, deposits in mutual savings banks in New Jersey paid no more than $4 \%$ or $4.5 \%$ interest (Piquet, p. 111). B\&L earnings were higher on average because members participated fully in the earnings on their association's portfolio of home mortgages. Attractive returns generated increases in membership of 141 and percent between 1920 and 1928 (5-12 million) compared to growth of just 32\% in savings bank membership (11.4-15 million). Total B\&L assets also grew relatively rapidly; by $318 \%$ (from $\$ 2.5$ to $\$ 8.0$ billion) between 1920 and 1928 while the assets of mutual savings banks increased by only $60 \%$ ( $\$ 7.1$ to $\$ 11.4$ billion).

12 More than 5000 B\&Ls were established and began operation during the urban building boom of the 1880s. During the housing boom of the 1920s, more than 3000 new B\&Ls appeared. In both periods B\&Ls grew in number and importance in all regions and states, and in cities of all sizes. See Snowden (2003).
}

\subsection{Building $\mathcal{E}$ Loans were member-owned, cooperative mortgage} lending corporations

The heart of the traditional B\&L was the share accumulation contract. Upon joining a B\&L each member agreed to purchase one or more shares in the association by making weekly or monthly installment payments, called dues. In a typical New Jersey B\&L, for example, members pledged to pay monthly dues of $\$ 1$ to purchase B\&L shares that had par values of $\$ 200$. The B\&L invested these funds in local home mortgage loans and paid dividends to members from profits earned on the mortgage loans in proportion to their paid-in investments in the association. If the B\&L paid annual dividends of $6 \%$, for example, the combined value of a member's dues and dividends reached its $\$ 200$ par value after 139 months. The time it took to reach par value was longer if dividends fell below $6 \%$ and shorter if they averaged more.

Three features of the share accumulation plan made the traditional B\&L a unique financial intermediary. First, weekly or monthly share accumulation payments were not deposits; they were equity contributions so that all B\&L members were owners of the association and fully shared in its profits and losses. Second, members who joined to borrow from the association were required to participate in the same share accumulation plan that non-borrowing members used for their savings. For borrowing members their investment in B\&L shares went into a sinking fund that was used to repay their loan. Third, borrowing members were at the same time debtors to and owners of their associations; they shared profits and losses on an equal basis with nonborrowing members and enjoyed the same one-member-one-vote voting rights. This third feature of the traditional B\&L created divergent interests between borrowing and non-borrowing memberowners when an association became distressed. This proved to be instrumental in delaying resolution within the industry during the 1930s housing crisis.

To clarify the dual status of a B\&L borrowing member, it is useful to describe the structure of the hybrid B\&L mortgage loan in more detail. The loan combined two features: an interest-only, balloon loan and the requirement that the borrower enter a share accumulation contract (SAC) equal in value to the principal of the loan. To secure a $\$ 2000$ home loan at an interest rate of $6 \%$, for example, a B\&L borrower agreed to purchase ten shares of the association each with a maturity value of $\$ 200$ each. Under the combined loan and share accumulation contracts, the borrower had to pay $\$ 10$ each month in "dues" on her shares (\$1 per share for each $\$ 200$ share) and another $\$ 10$ each month in interest on the balloon loan (6\% of the $\$ 2000$ loan divided by 12 months). ${ }^{13}$ The dues payments went into a "share account," which was a sinking fund where the dues accumulated into shares. Dividend payments from the B\&L also went into the share account. When the amount in the share account "matured" by matching the $\$ 2000$ principal on the loan, and not until then, the borrowing member's share account was used to repay and cancel her loan. The B\&L shares were generally structured to mature in 11 or 12 years, but could mature more quickly if dividend rates were higher than expected, or the time to maturity could lengthen if dividend rates were lower. If the borrowing member defaulted on dues or interest payments before the shares matured, the association could foreclose upon the property and seek full repayment from the borrower's share account and the proceeds from renting or selling the property.

\footnotetext{
13 If the market interest rate at the time of the loan differed from the dividend rate at the time the loan was taken out, the borrowing member might pay an additional premium payment each month or make a lump sum payment at the time of the loan.
} 


\subsection{Non-borrowing BEL members had limited withdrawal privileges}

B\&L share accumulation plans were marketed as programs that encouraged and rewarded regular patterns of savings over long horizons. To encourage regularity, B\&Ls charged fines to nonborrowing members who did not keep current on payment of dues. Non-borrowers were also assessed fines and forfeited some dividends, if they withdrew their B\&L shares before they had fully matured. Penalties on early withdrawals were structured so that the net return to a shareholder was negative or just above zero within the first two years of the share accumulation contract, and then gradually approached the expected full maturity return after that (Clark and Chase, 1925, 176). The penalties for early withdrawal were unpopular, but without some restrictions on withdrawals the B\&L could not have invested almost exclusively in illiquid residential mortgages in pursuit of their stated goals of financing homeownership and encouraging long-term saving. Even more fundamentally, a "withdrawal" of shares from a B\&L represented a repurchase of one member's equity by the remaining owners in the association. From this perspective, limitations had to be placed on withdrawals because a jointly-owned association could not knowingly impose losses or additional illiquidity upon the general membership by repurchasing shares to meet the needs and preferences of any one member (Sundheim, 1922, 153).

Despite the restrictions and penalties on early withdrawals that were built into B\&L bylaws, a national survey in 1920 found that between $35 \%$ and $90 \%$ of B\&L shares were withdrawn before maturity (Clark and Chase, 1925, 170). ${ }^{14}$ These high rates reflected and were encouraged by a general relaxation within the industry of the requirements that members provide 30-day written notification and pay a penalty for an early withdrawal (Clark and Chase, 1925, 185). The relaxation was possible because the rapid expansion of B\&Ls during the 1920s generated substantial inflows of dues each month that could accommodate both withdrawals and new loan investments. The trend to liberal withdrawal policies was so strong during the 1920s that a study of liquidity practices among New Jersey B\&Ls at the end of the decade concluded that "building and loan practice uniformly defines [a B\&L member's] status as that of a profit-sharing depositor." (Gardner, 1931, 5)

The New Jersey study also concluded, however, that B\&L withdrawal practice on the eve of the Depression did not uniformly reflect B\&L philosophy or financial practice. Opinions among B\&L practitioners regarding the provision of liquidity ranged from traditionalists who believed that "liquidity of any nature is inconsistent with the underlying philosophy of B\&L" to those who held that both justice and competitive survival required that B\&Ls provide their members with complete liquidity (Gardner, 1931, 811). Financial policies that supported liquidity were also scattered unevenly within the industry. Forty percent of New Jersey B\&Ls in 1929 held insufficient liquid resources to cover current obligations, and in half of these associations the deficiency was serious (Gardner, 1931, 17-31). ${ }^{15}$ These non-liquid B\&Ls were found in all

\footnotetext{
14 Piquet (1931) (Building and Loan Associations in New Jersey, 1931, Chapter V and Appendix J) compares the withdrawal behaviors in $\mathrm{NJ}$ of depositors in savings banks, B\&L members with installment shares, and B\&L members with "paid up" shares. The latter form of investment had become popular the 1920s, and some within the B\&L industry argued that paid up shares exposed the B\&Ls to the same kinds of liquidity concerns as a savings deposits. Piquet found that between 1900 and 1927 annual withdrawals from savings deposits averaged 95\% of deposits, that annual withdrawals from B\&L installment shares represented $43 \%$ of dues paid in, and withdrawals from paid up B\&L shares $70 \%$ of new receipts.

15 Gardner (1931, 20-30) conducted a survey of B\&Ls in NJ asking them to report for October 31, 1929. Liquid resources were defined as cash on hand plus average cash receipts, while current liabilities were defined as borrowed money overdue, unpaid matured shares, unpaid withdrawal applications on installment shares and amounts due on mortgage loans that had been granted. The difference between each association's reported cash on hand and these total current obligations rep-
}

the state's counties and included both large and small associations located in both large and small cities. B\&Ls like these relied on lines of credit at commercial banks to finance liquidity deficiencies when they arose (Gardner, 1931, 14, 105).

Gardner's study of liquidity was undertaken to help the New Jersey Building \& Loan League determine whether liquidity was "necessary or desirable" for its members and, if so, whether there were systems operating in other states at that time that could successfully support B\&L liquidity in New Jersey. ${ }^{16}$ Despite the wide differences in attitudes and financial policies related to liquidity within the state's industry, the League concluded that greater liquidity should be adopted as an industry norm and supported by a dedicated B\&L liquidity facility (New Jersey Building and Loan League, 1931, 6-8). Attempts to create such supportive systems in other states, however, were judged to be either ineffective or unsuitable for New Jersey conditions, so the League drew up and endorsed its own proposal for a cooperatively-funded liquidity facility. ${ }^{17}$ The plan was not implemented, however, because by 1931 few New Jersey B\&Ls could contribute to a cooperatively-financed liquidity system and in 1932 the Federal Home Loan Bank Act created a federally-sponsored discount facility for B\&Ls.

By 1930 a precarious incongruity had developed between the liquidity practices of B\&Ls and both their capacity to provide liquidity and their contractual obligation to protect the general membership against excessive withdrawals. The housing crisis quickly resolved this misconception. B\&L statutes regularly required that "at no time shall more than one-half of the funds in the Treasury [of a B\&L] be applicable to the demands of withdrawing stockholders without the consent of the Board of Directors." 18 If funds in a B\&L treasury were insufficient to meet withdrawal requests, then directors were required and empowered to suspend withdrawals beyond the notification window and until sufficient treasury funds were available. Once withdrawals had been suspended, moreover, the priority given to members had to be determined solely by the date they had requested their withdrawals. This meant, in particular, that no priority for withdrawals could be given to members who held matured shares relative to those requesting early withdrawals; nor could members accelerate a withdrawal by paying a premium to the association. ${ }^{19}$ The obligation to treat members equally and in their collective best interest led B\&Ls to suspend withdrawals indefinitely in the heart of the mortgage crisis and eventually to develop the rotation principle for distributing withdrawals. $^{20}$

Restrictions on the withdrawal of shares by a borrowing member of a B\&L were much simpler. First, a borrowing members could

resented a measure of net liquidity, and was then normalized as a fraction of its average monthly cash receipts.

16 The Board of Governors of the New Jersey League created a committee at its September 1930 meeting to investigate and report on "does the Building and Loan structure require a greater amount if liquidity and, if so, how should it be accomplished?" (New Jersey Building and Loan League, 1931, 5)

17 The League's proposal was built in four principals: 1) the system would be built by collective pooling of reserves; 2) membership would be mandatory for all $\mathrm{N}$ B\&Ls; 3) the system would be permanent rather than structured to operate only in general emergencies and 4) the system would be under the control of the B\&L industry.

18 In citing the 1874 Pennsylvania law, Sundheim, 1922, 152 observes that "statutes in the various jurisdictions usually contain ....a similar proviso". He shows in New Jersey (p. 253), for example, "not more than one-half of the receipts of any one month shall be required to be used for the payment of withdrawal claims."

19 Endlich $(1895,105-7)$ and Sundheim $(1922,153)$. The B\&L could also not differentiate in priority for withdrawals between the traditional installment shares and the "full-paid" share that became widely used in the 1920s.

20 B\&Ls that adopted the "rotation principle," during the 1930s set a fixed dollar limit for withdrawals each month and members queued up to receive it. Once they had received this fixed amount, they were then placed at the back of the line to wait for their next fixed payment. It took some members several years to withdraw all of their investment under this system (Bodfish and Theobold, 1938, 161). 
not withdraw shares without fully repaying their loans. Second, borrowing members could use unmatured shares and additional funds to prepay their mortgage loan at any time (Sundheim 1922, 168; Endlich (1895, 144). Such "withdrawals" drained no funds from the association's treasury and so could not be suspended. This ability to repay at any time played an important role in determining the borrower's incentives to delay the closing of the B\&L.

\subsection{BEL insolvency was rare; liquidation generally had to be triggered by a vote of members}

A B\&L could not be closed because it was illiquid. B\&Ls were member-owned corporations that were not obliged to repurchase the shares of their owners on demand. It turns out that B\&Ls also rarely became insolvent. A survey of available state supervisory reports in 1925 found there had been no reports of B\&L failures in 24 states and only 88 failures reported across the entire industry since around 1890 (Clark and Chase, 1925, 15). ${ }^{21}$ B\&L advocates pointed to the small number of failures as evidence of safety and soundness. A more accurate characterization, however, would have been that the unique character of the traditional B\&L insured that "failures" within that industry-using the common understanding of the term-would be rare:

The insolvency of [a building and loan] is sui generis. There can be, strictly speaking, no insolvency, for the only creditors are the stockholders by virtue of their stock.

Braver (1936, 1345-6).

The meaning of insolvency for B\&Ls was unique because their business was confined to raising capital from their member-owners and making loans to a subset of the same group (Endlich 1895, 497; Sundheim 1922, 179). The traditional B\&Ls in most states were not allowed to take deposits. ${ }^{22}$ B\&Ls were also restricted in their use of other forms of borrowing to conduct their business. ${ }^{23}$ With such limited reliance on creditors:

It is scarcely conceivable that the assets of a building association should shrink in so remarkable a manner as to leave such claimants in a position of inability to reimburse themselves by process of law. No case, it is believed, has occurred in which this was a ground for a successful appointment of a receiver.

Endlich $(1895,497)$.

Building \& Loans were exempted from the U.S. bankruptcy code in 1932, in fact, because it was widely recognized that they were not vulnerable to insolvency due to the actions of external creditors (U.S. House of Representatives, 1932).

As a B\&L suffered distress, the issue of insolvency did arise, however, because withdrawing members who had not been paid became general creditors in law and could sue for restitution after

\footnotetext{
21 Clark and Chase $(1927,365)$ conducted the survey by consulting the state regulatory reports that were then available at that time. The periods covered by this survey varied by state, but rarely extended to before 1890 when only a few states systematically regulated B\&Ls. Nonetheless, the annual reports revealed that no B\&L failures had been reported in 24 states up to that time. Excluded from these counts were the planned closings of what were known as "terminating" B\&L associations and a wave of failures during the early 1890s among a group of "national" building \& loans that unsuccessfully attempted to deploy the local building \& loan model over multi-state markets. Snowden $(2003,172-8)$ examines the reasons for and impacts of the failures of the national associations.

22 In the early 1920s 30 states, including New Jersey, prohibited B\&Ls from taking deposits, and only 3 (Ohio, Missouri and Arizona) permitted them. The remaining states, some of which had not yet enacted specific B\&L regulation, remained silent on the issue (Clark and Chase 1925, 396).

${ }^{23}$ B\&Ls generally borrowed only from a bank to smooth the seasonal demand for mortgage loans with the steady payment of stock subscriptions. All states limited borrowing to one year and most limited it to 20-25\%, although New Jersey's limit was 30\%. See Clark and Chase (1925, 125-6 and 403-8).
}

the notification period for withdrawals had passed. In these cases, the court was left to identify the conditions under which an association could be judged "insolvent." Over time, case law settled on a deceptively simple standard. A B\&L was insolvent when the assets of the association became insufficient to repay on a "dollar for dollar" basis the dues that its members had paid into their share accounts (Sundheim, 1922, 179; "Rights of depositors...," Yale Law Review, 1933, 932). The rationale for this standard was the presumption that an association in this condition could no longer fulfill the function it had been created to perform for its owners (Braver, 1936, 1346).

The inability to repay the equity contributions of B\&L members was a sensible standard for insolvency, but one that was difficult to implement since it required the court to assess the net worth of an operating entity. This difficulty was not mitigated, moreover, when a series of court decisions ruled that more obvious factors-such as an empty treasury, a suspension of withdrawals, or the appointment of a receiver by the state due to the negligence or malfeasance of an association's directors-did not represent determinative evidence regarding insolvency (Sundheim, 1922, 180; Braver, 1936, 1347). As a result, a member or group of members of a B\&L that alleged its insolvency bore the burden of proof that the value of the association's assets was not greater than the contributions of equity made by the members. It was difficult if not impossible for them to do so, however, because the money value of an association's assets could only be determined by liquidating its loans and real estate holdings-but by liquidating these the association became dissolved. The courts, therefore, could not settle the issue of insolvency without ordering the liquidation of an association that they were required to presume was solvent. ${ }^{24}$

There was, therefore, no statutory basis or court remedy through which a B\&L could be forced into insolvency. The state or court could appoint receivers to manage the B\&L, but only if the association was "exceeding its powers, or violating the law, or that its conditions or methods of business would render the continuation of its operation hazardous to the public or those having funds in its custody" (Braver, 1936, 1380). Absent these circumstances, a member-owned, equity-financed B\&L was presumed to be performing its intended function until its owners chose to liquidate the firm and surrender its charter (Endlich, 1895, 486). To do so, the members had to approve a resolution of voluntary liquidation. Although there was a presumption that liquidation required a unanimous vote of the members, this requirement could be overridden within the B\&Ls charter. For the case that we examine here, the New Jersey B\&L Law of 1904 permitted voluntary liquidation and dissolution with the approval of two-thirds of the stockholders attending a meeting that was called specifically to consider that motion (Sundheim, 1922, 258; Prescott, 1931, 200). ${ }^{25}$

\subsection{Borrowing members had incentives to delay voluntary liquidation}

During the housing crisis of the 1930s most B\&Ls became distressed, just like all other residential mortgage lenders. However,

\footnotetext{
24 "The difficulty with such a hard and fast definition is that the value of "available and collectible assets" cannot be really be determined until the association attempts to convert its securities into cash which, in turn, can only be effectively done upon liquidation." ("Effect of insolvency...," University of Pennsylvania Law Review, 1933).

25 Prescott $(1931,200)$ cites Section 31 of the law to read "A resolution to dissolve is adopted by the board of directors when in their judgment such course is deemed best. A notice of adoption is sent to each member stating the time and place of the shareholders' meeting for action thereon. At the meeting, an affirmative vote of two-thirds in interest of the members present is required for the adoption. A copy of the resolution must them be filed with the Commissioner of Banking and Insurance, whereupon a certificate to the trustees in liquidation may be issued by him."
} 
B\&Ls were unlike other intermediaries in that they did not have to close when they became illiquid and could not be declared insolvent by creditors. So, thousands of "frozen" B\&Ls continued to operate during the 1930s even though they had suspended withdrawals, had stopped making new loans, and were focused primarily on servicing loans that were still in good standing and foreclosing upon those that had fallen into arrears. B\&Ls in this condition could operate indefinitely unless and until its members approved a voluntary liquidation.

Upon an approval of liquidation, all contracts between the B\&L and its members were rescinded (Sundheim, 1922, 183-40; Braver, 1936, 1349-50). Non-borrowing members were no longer required to pay dues on their share accumulation contracts and could no longer take or request a withdrawal. A borrowing member also no longer had to pay dues on the share account that secured her loan, but the loan itself became immediately due in full. The loan was not in default, however, and the borrower was required to continue to make payments of interest on it, and still owed the principal. With all these contracts laid aside, the trustees were free to dispose of the association's assets and distribute the proceeds to members in shares proportional to their contributions of equity into the association.

A substantial body of case law developed over the years concerning the priority of different classes of non-borrowing stockholders during the distribution of the liquidated assets. Some members owned shares that had matured, others had filed notifications of withdrawal before the voluntary liquidation was approved, and still others had purchased full paid stock rather than through a share accumulation contract ("Rights of depositors...," Yale Law Journal, 1933, 935-40). The courts generally recognized priorities or preferences that had been granted before the liquidation had been approved or even anticipated, but once in liquidation shareholders were generally awarded claims proportional to the equity they had paid into the association regardless of differences in the maturity or types of shares they had held.

An issue of greater concern here regards the treatment of borrowing members during a voluntary liquidation. To confront the issue, courts had to clarify the status of the claims of borrowing members given that they were both owners of and debtors to their associations. The view held in the great majority of states, including New Jersey, was known as "the Pennsylvania Rule," named after the state where the key court decision was made. ${ }^{26}$ Under the Pennsylvania Rule the SAC borrower was both a bona fide member/owner of the B\&L and a debtor to the B\&L. The rationale for this position was that the share account attached to the SAC member's loan earned the same profits and absorbed the same losses as the share accounts of non-borrowing members. Thus, when a resolution for voluntary liquidation had been passed, the borrowing member's loan became immediately due in full, while the shares built up in the associated sinking fund were held back until the B\&L had disposed of all its assets and declared a liquidating dividend.

Under the Pennsylvania Rule borrowing members in a distressed association had incentives to delay liquidation until they could pay off their share accumulation loan contract as originally written. If a borrowing member could pay off the loan prior to liquidation, his shares were assessed at their book value and were

\footnotetext{
${ }^{26}$ A handful of states dealt with SAC borrower/members with the "Maryland rule." Under this interpretation the dual role of stockholder-mortgagor was treated as a fiction imposed by the B\&L contractual structure. As a result, the borrowing member was considered to be a debtor with a liability equal to the difference between her outstanding straight mortgage loan and the balance in her share account. Under insolvency, therefore, the borrower became responsible for a loan balance equal to the difference between her share account and the original loan balance. This NET debt was calculated based on the book value of her shares and became due immediately.
}

not written down to account for losses embedded in the association's balance sheet. If the loan was still outstanding at liquidation, on the other hand, his shares fell to their liquidation value and he still owed the full, original principal of his loan. We estimate below that the liquidation value of B\&L shares were typically two-thirds of their book value; therefore, repaying a loan after liquidation imposed a sizeable loss on the B\&L borrower. ${ }^{27}$ This loss also raised the probability that the borrower would default on the loan and lose his home, in which he typically held 40 to 50 percent equity during this period.

Given the divergent incentives of borrowing and non-borrowing members, it is likely that their relative numbers influenced the decision to voluntarily liquidate. More specifically, SAC borrowing members could effectively block dissolution if they accounted for more than one-third of the members who attended and voted at the special meeting called to consider the resolution to liquidate. As we will further explain in the data and descriptive statistics section, we can only construct a proxy for the share of SAC members that had the opportunity to block the liquidation in the special meeting, due to two reasons. First, we have an estimate of the share of SAC borrowers among all members, and not those who attended and voted on these resolutions. SAC borrowers had more at stake in the vote than the non-borrowing members and thus were more likely to attend these meetings. Second, our measure of the share of SAC borrowing members is an estimate for each association based on an assumption about the relative average sizes of SAC and non-SAC loans. It follows, therefore, that our empirical model of voting should treat the one-third requirement as a "fuzzy" threshold. To take these considerations into account, in the estimation below we use a set of variables that indicate different levels of the share of SAC members, and we also estimate the impact of the percentage of SAC members measured as a continuous variable in modeling the decision to liquidate a B\&L. In the robustness checks section, we show, through both graphs and regression analysis, that the results do not change if we limit the analysis to a small interval around the cutoff of one-third share of SAC members.

\section{Data and descriptive statistics}

To examine the impact of the two-thirds majority rule for dissolution, we have collected and digitized a panel dataset with timevarying information on the features of the balance sheets of all the B\&Ls operating in New Jersey in the 1930s. We chose New Jersey for several reasons. First, it is the only state in which the state regulator consistently reported the number of borrowing and nonborrowing members as well as balance sheet information for each B\&L for each year in the 1930s. Second, New Jersey had a large number of B\&Ls spread throughout the counties of the state. Third, few of the B\&Ls in New Jersey converted to the Savings and Loan structure; therefore, we can look specifically at voluntarily liquidations without facing the complications in incentives created by the conversion to S\&Ls and the attempts to shift borrowers into S\&L contracts.

The information on individual B\&Ls was collected, compiled, and digitized from the Annual Reports of the Commissioner of Banking and Insurance in New Jersey for the years 1930 through 1940. The sources provide the name, location, and date of establishment

\footnotetext{
27 Rose (2014) examines in detail the operation of the curb market for B\&L shares in New Jersey during the 1930s and shows that it provided withdrawals at deep discounts for B\&L members and offered purchasers control over the foreclosed real estate owned by the association. In his examination of the Milwaukee situation, Kendall $(1962,146)$ examines secondary market prices for nearly one hundred Milwaukee B\&Ls in 1936 and finds that B\&L members sold shares at prices that ranged from $\$ 15$ to $\$ 86$ for each $\$ 100$ "par" share. The average discount was $20-30 \%$ relative to their book values.
} 
Table 1

Means and standard deviations from New Jersey sample of Building \& Loans that survived or voluntarily liquidated between 1934 and 1940 .

\begin{tabular}{|c|c|c|c|c|c|}
\hline & & 1930 & 1934 & 1939 & $1934-1940$ \\
\hline \multirow[t]{2}{*}{ SAC borrowers as share of members } & Mean & 0.235 & 0.263 & 0.16 & 0.214 \\
\hline & Std. dev. & 0.117 & 0.123 & 0.121 & 0.129 \\
\hline \multicolumn{6}{|l|}{ Dummies: SAC borrowers share of owners is } \\
\hline \multirow[t]{2}{*}{ More than one-third } & Mean & 0.187 & 0.266 & 0.106 & 0.199 \\
\hline & Std. dev. & 0.390 & 0.442 & 0.308 & 0.399 \\
\hline \multirow[t]{2}{*}{ Between one-third and one-fourth } & Mean & 0.188 & 0.218 & 0.132 & 0.192 \\
\hline & Std. dev. & 0.391 & 0.413 & 0.339 & 0.394 \\
\hline \multirow[t]{2}{*}{ DRC borrowers as share of members } & Mean & 0.003 & 0.01 & 0.056 & 0.029 \\
\hline & Std. dev. & 0.009 & 0.022 & 0.06 & 0.049 \\
\hline \multicolumn{6}{|l|}{ Shares of assets } \\
\hline \multirow[t]{2}{*}{ Cash on hand } & Mean & 0.016 & 0.021 & 0.028 & 0.024 \\
\hline & Std. dev. & 0.023 & 0.03 & 0.043 & 0.034 \\
\hline \multirow[t]{2}{*}{ Arrearages } & Mean & 0.015 & 0.052 & 0.027 & 0.039 \\
\hline & Std. dev. & 0.015 & 0.046 & 0.044 & 0.049 \\
\hline \multirow[t]{2}{*}{ Value of real estate owned } & Mean & 0.033 & 0.225 & 0.385 & 0.339 \\
\hline & Std. dev. & 0.048 & 0.136 & 0.196 & 0.183 \\
\hline \multirow[t]{2}{*}{ Natural log of total assets } & Mean & 13.678 & 13.847 & 13.451 & 13.626 \\
\hline & Std. dev. & 1.084 & 0.955 & 0.886 & 0.922 \\
\hline \multicolumn{6}{|l|}{ Shares of liabilities } \\
\hline \multirow{2}{*}{ Installment dues } & Mean & 0.676 & 0.59 & 0.442 & 0.516 \\
\hline & Std. dev. & 0.097 & 0.111 & 0.164 & 0.15 \\
\hline \multirow[t]{2}{*}{ Paid-up shares } & Mean & 0.078 & 0.101 & 0.129 & 0.116 \\
\hline & Std. dev. & 0.089 & 0.104 & 0.116 & 0.113 \\
\hline \multirow[t]{2}{*}{ Unapportioned profits } & Mean & 0.007 & 0.118 & 0.212 & 0.167 \\
\hline & Std. dev. & 0.009 & 0.054 & 0.097 & 0.082 \\
\hline \multicolumn{6}{|l|}{ County variables } \\
\hline \multirow[t]{2}{*}{ Retail sales per capita } & Mean & 447.57 & 290.202 & 396.125 & 357.94 \\
\hline & Std. dev. & 102.63 & 60.426 & 71.804 & 80.942 \\
\hline \multirow[t]{2}{*}{ Value of HOLC loans refinanced per household } & Mean & 0.000 & 893.298 & 0.000 & 121.439 \\
\hline & Std. dev. & 0.000 & 401.511 & 0.000 & 337.872 \\
\hline \multirow[t]{2}{*}{ Federal tax returns filed per capita } & Mean & 0.051 & 0.053 & 0.094 & 0.081 \\
\hline & Std. dev. & 0.018 & 0.017 & 0.022 & 0.041 \\
\hline
\end{tabular}

for each association that operated between 1930 and 1940, as well as comprehensive balance sheet information for each year. It also identifies B\&Ls who have exited each year and the type of exit.

A total of 1581 associations operated at some time during the decade in New Jersey and there was wide variation in age and size. In 1930 of the 1561 operating B\&Ls there were 283 associations operating that had been established before 1900, another 585 had been placed in operation between 1900 and 1920, and 693 had been organized during the rapid expansion of the 1920s. Another 20 B\&Ls were formed after 1930 . The size also varied considerably. More than 400 small associations held total assets of less than $\$ 250,000$ while another 92 held more than $\$ 2$ million. Membership numbers correlate closely with total association size, as 240 small associations had fewer than 250 owner-members and 297 claimed more than 1000 members. All told, the average association in New Jersey held assets of $\$ 633,000$ in 1930 and claimed 528 members of which 123 were borrowers.

The detailed balance sheet data provided in the annual reports provide a rich set of measures of each association's financial structure and strength that we use here as controls for the probability of exit. Table 1 shows the means and standard deviations for these variables for several years during the 1930s. In our regressions in the next section, we control for the size of the association's total assets, and use the shares of total assets represented by key assets and liabilities to measure their financial condition. The principal earning assets for a healthy B\&L were mortgage loans and these represented an average of 90\% for operating associations in 1930. As the housing crisis unfolded, the average share of mortgages fell to lows of only $50 \%$ in 1937 and then recovered to $58 \%$ by the end of the decade. Offsetting increases in the shares of two other assets trace the dynamics of the difficulties B\&Ls faced during the crisis. Nonpayment of dues on stock subscriptions and interest on loans were classified as "arrearages," and the average share of assets in this category increased from less than $1 \%$ in 1930 to $5 \%$ in the mid1930 s before falling back to $2 \%$ in 1940 . Increases in arrearages on loans and shares securing loans were signs of problems and often were followed by loan foreclosures. Increased numbers of foreclosures caused the average share of assets represented by real estate owned by the B\&L to increase from 3\% in 1930 to nearly $40 \%$ as late as 1939. The annual shares of mortgage loans, arrearages and real estate owned for the B\&Ls in our sample together give a rich and dynamic picture of their basic profitability and solvency and we supplement that here with a measure of their short-run liquidity-the share of assets held in cash.

The liabilities reported in the annual reports characterize the structure of claims on each B\&L's assets that were held by its member-owners. In 1930 most of the capital invested in New Jersey B\&Ls ( $84 \%$ on average) came through the traditional channeldues paid on installment shares and the profits on these shares that had been apportioned by the B\&L and accumulated in the members share account. As distress mounted, B\&Ls built loss reserves and sought greater liquidity by holding back on payments of dividends and retaining profits to serve as loss reserves and to fund greater liquidity. These un-apportioned profits -which legally belonged to members- became a major liability, rising from one percent in 1930 to more than $20 \%$ by the end of the decade, as shown in Table 3. Also by the end of the decade the more modern form of investment that would become the standard liability in the postwar S\&L-paid-up shares-increased in importance as a share of liabilities.

The annual reports provide information in each year on the number of borrowing and non-borrowing members in each B\&L. The voting bloc of most interest here is borrowing members, but more specifically borrowing members with traditional B\&L share 
accumulation, sinking-fund loans. One of the important changes in the transition from B\&L to S\&L was the replacement of the traditional share accumulation loan (henceforth SAC) with the modern direct reduction loan contract (DRC) in which monthly principal payments were used to immediately reduce the outstanding loan balance. The impact of a voluntary liquidation on DRC borrowers, and their likely voting positions, were different because under liquidation the dues payments the SAC borrowers had made into their sinking funds were held back and subject to the member's share of association losses. So although the loans of both SAC and DRC borrowers became due immediately upon liquidation, under the traditional contract the borrower owed the original loan amount while the DRC owed only the remaining principal.

The New Jersey B\&L reports are unusual because they report for each year not only the number of borrowing and non-borrowing members, but also the breakdown of mortgage loans into the volume of SAC and DRC loans. As a result, we can estimate the number of SAC and DRC borrowing members in each B\&L by multiplying the total number of borrowers by the shares of the two loan types in total mortgage lending volume. ${ }^{28}$ As can be seen in Table 3, the share of members who borrowed under a direct reduction mortgage contract was very small in New Jersey over this decade, accounting for less than 2.5\% of members through 1938 and then rising to $5.6 \%$ in 1939 as the dissolution of traditional B\&Ls accelerated. The share of members who had borrowed using SAC contracts was a much larger voting bloc, on the other hand, and represented an average of $23 \%$ of members in 1930 and $26 \%$ in 1934 before falling off rapidly in the last few years of the decade.

The New Jersey data, therefore, allow us to divide B\&L membership each year into three groups-SAC borrowers, DRC borrowers and non-borrowers. We treat all non-borrowers as a single voting bloc here because non-borrowers were treated equally when associations became frozen or liquidated whether they held installment, matured, or paid-up stock. Our focus is on the share of SAC borrowers and the requirement in New Jersey law that a voluntary liquidation had to be approved by at least two-thirds of all members that attend the meeting. In our main specification, we estimate the impact of SAC membership shares by creating a dummy variable for B\&Ls in which the share of SAC borrowers in that year accounted for more than or equal to one-third of the voting members and thus could block liquidation. Because attendance at dissolution meetings was voluntary, the number of members and the attendees might differ, which would add some additional fuzziness as to who might actually participate in the voting. To allow for this fuzziness and the possibility that borrowers were still able to block liquidation with a lower share, we add a second dummy for settings when the share was greater than or equal to $25 \%$ and less than one-third. As shown in Table 3, SAC borrower voting blocs were sufficiently large to determine voting outcomes in nearly $20 \%$ of B\&Ls over the entire 1930s decade and just under that size in another $20 \%$. We also estimate the impact on the hazard of the share of SAC borrowers to allow comparisons of the size of the effects on dissolution of changes in the SAC share and changes in features of the balance sheet.

Not all the New Jersey B\&L closures were voluntary liquidations. Of the 568 closures between 1934 and 1940, 351 were voluntary liquidations, 93 involved mergers, 31 were reorganizations, 6 were conversions to Federal S\&Ls and 87 were driven by state action. Most of the reorganizations involved "bulk transfers" of assets in which the membership of an association segregates non-

\footnotetext{
28 The maintained assumption is that the size of SAC and DRC loans were on average the same. The categories of loans reported in the annual report are "Mortgage Loans-With Pledged Shares" and "Mortgage Loans-Without Pledged Shares". The latter could include both DRC and straight loans-we refer to them all as DRC which clearly become more important over the decade.
}

performing loans from good loans and places the good loans in a new B\&L in which each member was given a proportional share. The members accepted a write-down in the value of the shares in their original association so that the new "healthy" B\&L can begin to operate while the "bad loan association," was liquidated (Ewalt 1962, 116-8). The state actions included 21 liquidations and conservatorships run by the state regulator, likely for fraud. The remaining 58 occurred in only two years-1937 and 1940-and are described in the state reports as "the state taking possession." Most B\&Ls in this category continued to operate for a year or two before ending operations, but the annual report provides no clear information about how they were resolved. In the next section we focus on voluntary liquidations and we discuss the robustness of the results to considering other sources of exit. ${ }^{29}$

Finally, the empirical analysis focuses specifically on the 1934 to 1940 period during which voluntary liquidations accelerated and before state government and federal regulators began to sponsor large numbers of resolutions. By narrowing the focus to the period 1934 to 1940 our empirical analysis examines 992 B\&Ls that survived and operated until at least 1940, 351 B\&Ls that were voluntarily liquidated by their members between 1934 and 1940, and 170 B\&Ls who exited through mergers, federal conversions, reorganizations or state actions.

\section{Empirical strategy}

The empirical strategy of the paper identifies the effects of the share of SAC members on the timing of voluntary liquidations using a semi-parametric survival model of exit. For our baseline analysis we restrict our sample to B\&Ls that either exited through voluntary liquidation or survived until the end of our five-year sample period. Later in the paper we perform robustness tests for this limitation. ${ }^{30}$ Using these data we estimate a Cox (1972) survival model in which the hazard of closure through voluntary liquidation is:

$\mathrm{h}(\mathrm{t})=\mathrm{h}_{0}(\mathrm{t}) \exp \left(\beta \mathrm{SAC}_{\mathrm{itc}}+\delta_{1} \mathrm{~F}_{\mathrm{itc}}+\delta_{2} \mathrm{C}_{\mathrm{itc}}+\delta_{3} \mathrm{~F}_{\mathrm{i} 30 \mathrm{c}}\right)$

where $h(t)$ is the hazard of closure at time $t$. The subscript $i$ refers to the firm, $t$ to the year, and $c$ to the county where the firm is located. Survival models divide the hazard of exiting into two components: a) the baseline hazard $\left(h_{0}(t)\right)$ that defines the pattern of the baseline hazard of exit for all observations over time, and b) the differences in the hazard related to the covariates (the exponential of a linear index of covariates). The Cox model is a semiparametric technique that leaves the baseline hazard rate unspecified and imposes that the effect of covariates on the hazard rate for any individual is proportional to the baseline hazard. As a robustness check, in the Appendix we present the estimates for other survival models in which the baseline hazard $\left(h_{0}(t)\right)$ is assumed to have a parametric distribution (for example an exponential or Weibull distribution).

In our specification, $S A C_{i t c}$ is a vector of dummy variables that capture the impact of different ranges of the share of SAC borrowing members among all members. In our main specifications we use an indicator function that takes the value of one if the share of SAC members is between $1 / 4$ and $1 / 3$ and another indicator function that takes the value of one if the share of SAC members is greater than $1 / 3$. In other specifications we use the share of SAC

\footnotetext{
29 The strategy we employ is first to examine the timing of voluntary liquidations by using the first two groups, and then to investigate the robustness of the results by considering the impacts of the other types of exit in a multinomial logit analysis. In an appendix table we also show that the basic qualitative results are unchanged when we treat mergers and reorganizations as voluntary liquidations and when we estimate the model treating all closures as the same.

${ }^{30}$ See Section VIII for the multinomial logit analysis for the sample period in which all types of exits-mergers, conversion to federal charters and reorganizations as well as voluntary liquidations-are modeled.
} 
members as a continuous function. Our primary focus is on $\beta$, the coefficient(s) on the measure(s) of the proportion of SAC borrowers. ${ }^{31}$

The most complete specification of the model includes a rich set of correlates to control for omitted variable bias and potential selection bias. $F_{i t c}$ is a vector of time-varying firm characteristics, including size (measured as log of total assets), the share of DRC borrowing members and a series of variables describing the assets and liabilities. The asset variables include the shares of assets in arrears (non-payments), real estate owned, and cash on hand; the left out category is loans and miscellaneous assets. On the liability side we can also control for the shares of liabilities in installment shares, paid up shares, and un-apportioned profits with apportioned profits and miscellaneous as the left-out category. ${ }^{32}$

$C_{i t c}$ represents a vector of time varying measures of economic activity in the county where the B\&L was located. Retail sales per capita offers a measure of average consumption and federal tax returns filed per capita controls for the top end of the income distribution. These variables were drawn from data sets compiled by Fishback et al. (2011). We also developed a variable for the value of Home Owners' Loan Corporation (HOLC) loans purchased per household across New Jersey counties. ${ }^{33}$ The HOLC purchased mortgages from all types of New Jersey lenders and refinanced them for roughly $8 \%$ of households. Approximately $80 \%$ of the purchases were made in 1934 and 20\% occurred in 1935 and the shares varied across counties. We controlled for the value of the HOLC loans purchased per household in those years because somewhere between 33 and 50\% of the HOLC funds removed problematic mortgages from the B\&Ls balance sheets. ${ }^{34}$

The hazard model structure does not allow controlling for timeinvariant features of the B\&Ls with fixed or random effects. Following the practice in survival models estimation, to control for unmeasured time-invariant heterogeneity across firms, we include time-invariant controls for the asset structure and size of the firms in 1930 and/or the liability structure in 1930 just before the mortgage crisis started to develop.

Our baseline analysis uses the Cox proportional model because it does not specify a functional form and therefore is more flexible than other methods. To ensure that the results found here are

\footnotetext{
31 Because the SAC borrower shares may have some measurement error, we have tried alternative measures of the reliance on SAC loans. In one of them we use the SAC share of the value of loans, which focuses on the differences between DRC borrowers and SAC borrowers but ignores the non-borrowing members. In a second specification, we use the proportion of borrowing members in the total membership, which focuses on differences in attitudes between borrowers and nonborrowers but ignores differences between DRC and SAC borrowing members. The results in all settings suggest that greater reliance on SAC loans was associated with a lower probability that the B\&L would close.

32 Although the shares of assets and liabilities measure different elements of the financial structure and health of B\&Ls, there are strong connections between the structure of liabilities and the structure of assets. To see the robustness of results to multi-collinearity, we also estimated, but do not report, models with the variables describing the structure of assets and liabilities alone.

33 The HOLC reported the total distribution of loans and number of households that they made across each county in New Jersey; $80.7 \%$ of the New Jersey loans were distributed in 1934, and 19.26 were distributed in 1935. See Federal Home Loan Bank Board (1934, 86; 1935, 63; 1936, 164, 192-193). We used these percentages to apportion the loans for each county for 1934 and 1935.

34 The HOLC bought troubled mortgages from lenders and then refinanced them for borrowers in 1933 and 1934. This would have helped delay insolvency by removing a number of troubled mortgages from the B\&Ls' books. A rough estimate is that the HOLC purchased about $\$ 50$ million in mortgages from New Jersey B\&Ls in 1934 and 1935, which was about 20\% of the decline in B\&L assets during that period. Through 1935 about $8 \%$ of New Jersey nonfarm homes were mortgaged by the HOLC compared with $9.5 \%$ for the nation as a whole. New Jersey ranked 36th on that percentage. 5.3\% of HOLC loans. (Federal Home Loan Bank Board, 1935, p. 63, 1937, p. 164). The Federal Housing Administration (FHA) had relatively small impacts in New Jersey because it, insured a relatively small share of mortgages in NJ before the early 1940s.
}

robust, we have also estimated the relationships in several other ways. We explore use of exponential and Weibull parametric analysis. We have also estimated the survival model by treating other forms of exit as voluntary exits, and as non-exits. We have also estimated a multinomial logit model in each form of exit is treated as an outcome. Finally, we have reanalyzed the data using methods designed for discontinuous changes. In all cases the results lead to similar conclusions, so we report the robustness checks in Appendix A.

\section{Results}

In column 1 of Table 2 we model the hazard of exiting through voluntary liquidation as a function only of the voting bloc size of the borrowing members of $\mathrm{B} \& \mathrm{~L}$ associations. These estimates are based on maximum-likelihood estimates of Eq. (1). Dummies are included here to identify B\&Ls in which SAC borrowers were more than one-third of members, for associations with SAC borrowers between one-quarter and one-third of members, and with the actual share of DRC members. The negative and statistically significant coefficients imply that the probability of closure declined for B\&Ls with higher shares of SAC borrowers. B\&Ls with SAC shares greater or equal to one-third of voters were $75.7 \%$ less likely to close than B\&Ls with SAC shares below 25\%. B\&Ls with SAC shares between one-fourth and one-third were $63.6 \%$ less likely to close.

The estimated relationships above are unconditioned by the asset or liability structures of the B\&Ls. This likely means that there is omitted variable bias that overstates the ability of the SAC loan holders to stop voluntary liquidations. B\&Ls with higher shares of assets in real estate owned due to foreclosure were more likely to be in trouble and thus to have been closed. At the same time, foreclosure on loans and increases in real estate owned would have directly reduced the numbers of SAC borrowers and, therefore, their share of the membership. Taken together, these two influences should create an omitted variable bias in the negative direction if the SAC member share is estimated without conditioning on the share of real estate and other balance sheet variables that would bias the unconditional estimates toward being more negative. Consistent with the anticipated negative omitted variable bias, when we control for changes in the asset and liability structure of the B\&Ls in Specification 2 of Table 2, in fact, the coefficients on the SAC borrower share of borrowers become substantially less negative.

To mitigate problems associated with the potential endogeneity of the SAC loan member share, we add additional controls for the structure of the assets and liabilities for each B\&L in 1930. In a survival model, the balance sheet variables measured before the crisis can be considered as similar to fixed effects that control for the condition of each B\&L before the crisis. We also add measures of contemporary economic activity within the county in which each B\&L was located. When these additional factors are included in the analysis, the coefficients in column 3 of Table 2 become less negative but remain statistically significant for B\&Ls with a SAC share of voters greater than or equal to the one-third threshold required to block liquidation. The estimated coefficient for B\&Ls with SAC shares above one-third $(-.872)$ implies that these associations were $50.2 \%$ less likely to go into voluntary liquidation than ones with SAC shares below $25 \%$. The less negative estimate $(-.438)$ for SAC shares between one-third and one-fourth, on the other hand, indicates these B\&Ls were $24 \%$ less likely to close than those with less than a one-fourth share, but the relationship is statistically insignificant.

One way of illustrating the magnitude of the impact that borrowing members on liquidation is to calculate the change in the baseline probability of liquidation for the sample if the SAC mortgage shares of ownership had been greater than one-third in all 
Table 2

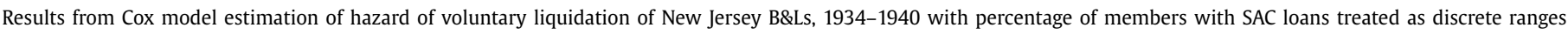
and as continuous variable.

\begin{tabular}{|c|c|c|c|c|c|c|c|c|}
\hline & \multicolumn{5}{|c|}{ Dummies for ranges of SAC borrower share } & \multirow{2}{*}{\multicolumn{3}{|c|}{$\begin{array}{l}\text { SAC borrowers as share of members } \\
\text { Coefficients and (standard errors) in } \\
\text { specification }\end{array}$}} \\
\hline & \multicolumn{3}{|c|}{$\begin{array}{l}\text { Coefficients and (standard errors) in } \\
\text { specification }\end{array}$} & \multicolumn{2}{|c|}{$\begin{array}{l}\text { Changes in predicted } \\
\text { probabilities for }\end{array}$} & & & \\
\hline & 1 & 2 & 3 & $\begin{array}{l}\text { Increase by one } \\
\text { std. deviation }\end{array}$ & $\begin{array}{l}\text { Change from } \\
1934 \text { to } \\
1939\end{array}$ & 4 & 5 & 6 \\
\hline SAC borrowers more than $1 / 3$ of members & $\begin{array}{l}-1.415^{*} \\
(0.195)\end{array}$ & $\begin{array}{l}-0.872^{*} \\
(0.295)\end{array}$ & $\begin{array}{l}-0.699 * \\
(0.281)\end{array}$ & NA & NA & & & \\
\hline SAC borrowers between $1 / 4$ and $1 / 3$ of members & $\begin{array}{l}-1.011^{*} \\
(0.210)\end{array}$ & $\begin{array}{l}-0.438^{*} \\
(0.186)\end{array}$ & $\begin{array}{l}-0.281 \\
(0.199)\end{array}$ & NA & NA & & & \\
\hline SAC borrowers' share of members & & & & & & $\begin{array}{c}-5.855^{*} \\
(0.9443)\end{array}$ & $\begin{array}{l}-2.499^{*} \\
(0.6457)\end{array}$ & $\begin{array}{c}-1.648^{*} \\
(0.7126)\end{array}$ \\
\hline DRC borrowers' share of members & $\begin{array}{l}-3.525 \\
(2.265)\end{array}$ & $\begin{array}{l}1.591^{*} \\
(0.768)\end{array}$ & $\begin{array}{l}1.613^{*} \\
(0.948)\end{array}$ & 0.013 & 0.012 & $\begin{array}{l}-5.337^{*} \\
(2.5203)\end{array}$ & $\begin{array}{l}1.2449 \\
(0.9587)\end{array}$ & $\begin{array}{l}1.4762 \\
(1.1749)\end{array}$ \\
\hline Natural log of (total assets) & & $\begin{array}{l}-0.635^{*} \\
(0.083)\end{array}$ & $\begin{array}{l}-0.600^{*} \\
(0.155)\end{array}$ & -0.066 & 0.042 & & $\begin{array}{c}-0.653^{*} \\
(0.0754)\end{array}$ & $\begin{array}{c}-0.601^{*} \\
(0.1548)\end{array}$ \\
\hline Share of assets in & & & & & & & & \\
\hline Real estate Owned & & $\begin{array}{l}4.086^{*} \\
(0.730)\end{array}$ & $\begin{array}{l}3.968^{*} \\
(0.646)\end{array}$ & 0.166 & 0.143 & & $\begin{array}{l}3.8127^{*} \\
(0.6638)\end{array}$ & $\begin{array}{l}3.8415^{*} \\
(0.6572)\end{array}$ \\
\hline Arrears & & $\begin{array}{l}7.256^{*} \\
\text { (1.099) }\end{array}$ & $\begin{array}{l}5.937^{*} \\
(1.133)\end{array}$ & 0.053 & -0.022 & & $\begin{array}{l}6.8456^{*} \\
(1.1524)\end{array}$ & $\begin{array}{l}5.8316^{*} \\
(1.1571)\end{array}$ \\
\hline Cash on hand & & $\begin{array}{l}-2.294^{*} \\
(1.271)\end{array}$ & $\begin{array}{l}-2.062^{*} \\
(0.819)\end{array}$ & -0.011 & -0.002 & & $\begin{array}{l}-2.857^{*} \\
(1.1108)\end{array}$ & $\begin{array}{l}-2.300^{*} \\
(0.8208)\end{array}$ \\
\hline $\begin{array}{l}\text { Share of liabilities in } \\
\text { Installment shares }\end{array}$ & & $\begin{array}{l}-1.523^{*} \\
(0.446)\end{array}$ & $\begin{array}{l}-1.892^{*} \\
(0.502)\end{array}$ & -0.039 & 0.051 & & $\begin{array}{l}-1.586^{*} \\
(0.3801)\end{array}$ & $\begin{array}{l}-1.860^{*} \\
(0.4635)\end{array}$ \\
\hline Paid-up shares & & $\begin{array}{l}-1.029 \\
(0.876)\end{array}$ & $\begin{array}{l}-1.731^{*} \\
(0.599)\end{array}$ & -0.028 & -0.008 & & $\begin{array}{l}-1.201 \\
(0.8275)\end{array}$ & $\begin{array}{l}-1.615^{*} \\
(0.5846)\end{array}$ \\
\hline Unapportioned profits & & $\begin{array}{l}2.086^{*} \\
(0.891)\end{array}$ & $\begin{array}{l}1.562^{*} \\
(0.886)\end{array}$ & 0.022 & 0.025 & & $\begin{array}{l}1.9192^{*} \\
(0.9458)\end{array}$ & $\begin{array}{l}1.5798^{*} \\
(0.9431)\end{array}$ \\
\hline County data & & & & & & & & \\
\hline Retail sales per capita & & & $\begin{array}{l}0.0003 \\
(0.003)\end{array}$ & 0.004 & 0.005 & & & $\begin{array}{l}0.0001 \\
(0.0032)\end{array}$ \\
\hline Federal tax returns filed per capita & & & $\begin{array}{l}5.691 \\
(5.261)\end{array}$ & 0.043 & 0.042 & & & $\begin{array}{l}5.6843 \\
(5.3857)\end{array}$ \\
\hline Value of HOLC loans per household & & & $\begin{array}{l}0.0003 \\
(0.001)\end{array}$ & 0.019 & -0.039 & & & $\begin{array}{l}0.0005 \\
(0.0009)\end{array}$ \\
\hline Information from 1930 & & & & & & & & \\
\hline Natural log of (total assets) & & & $\begin{array}{l}-0.0002 \\
(0.186)\end{array}$ & 0.000 & NA & & & $\begin{array}{l}-0.0033 \\
(0.1866)\end{array}$ \\
\hline Share of assets in & & & & & & & & \\
\hline Real estate owned & & & $\begin{array}{l}1.245^{*} \\
(0.478)\end{array}$ & 0.008 & NA & & & $\begin{array}{l}1.1268^{*} \\
(0.4560)\end{array}$ \\
\hline Arrears & & & $\begin{array}{l}9.317^{*} \\
(4.687)\end{array}$ & 0.019 & NA & & & $\begin{array}{l}8.9250^{*} \\
(4.3474)\end{array}$ \\
\hline Cash on hand & & & $\begin{array}{l}4.482^{*} \\
(1.919)\end{array}$ & 0.015 & NA & & & $\begin{array}{l}4.5036^{*} \\
(1.8953)\end{array}$ \\
\hline $\begin{array}{l}\text { Share of liabilities in } \\
\text { Installment shares }\end{array}$ & & & $\begin{array}{l}0.642 \\
(0.420)\end{array}$ & 0.010 & NA & & & $\begin{array}{l}0.5691 \\
(0.3752)\end{array}$ \\
\hline Paid-up shares & & & $\begin{array}{l}2.570 \\
(7.011)\end{array}$ & 0.014 & NA & & & $\begin{array}{l}0.7245 \\
(0.7806)\end{array}$ \\
\hline Unapportioned profits & & & $\begin{array}{l}0.970 \\
(0.806)\end{array}$ & 0.003 & NA & & & $\begin{array}{l}1.5392 \\
(7.3976)\end{array}$ \\
\hline
\end{tabular}

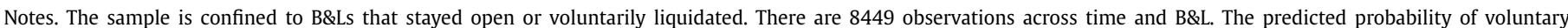

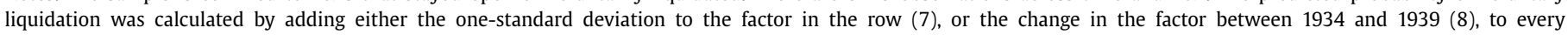

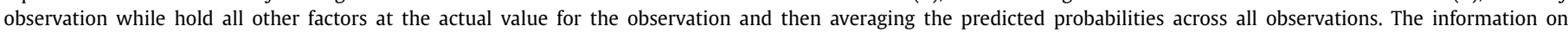
standard deviations and the change from 1934 to 1939 is in Table 1. ${ }^{*} p<0.05$.

New Jersey B\&Ls. To do so, we first calculate the predicted probability of liquidation for each B\&L in each year using the baseline probability estimated in the model, the coefficients from specification 3 in Table 2 and the actual values of each of the correlates. The mean of these predicted probabilities is $16.0 \%$, which represents the mean baseline probability of any B\&L in the sample failing in any given year between 1934 and 1940. When all firms are given a SAC share above one-third while leaving the rest of the correlate values the same for each observation, the predicted probability falls to 8.4 percentage points or to just under $50 \%$ of the actual sample's baseline hazard. If we redo this calculation by assuming all firms have SAC shares between one-fourth and onethird, the probability of liquidation falls from 16.0 to 11.8 percentage points, or a decrease of $26 \%$.

An alternative counterfactual method of showing the large magnitude of the impact of borrower's voting power is to show how the number of predicted liquidations each year and in total would have changed under different values of the share of members with SAC loans. The first column in Table 3 shows that the actual number of voluntary liquidations for B\&Ls in the sample in each sample year. Between 1934 and 1940, 351 New Jersey B\&Ls entered voluntary liquidation, with only 11 before 1936 and a peak of 
Table 3

Predicted number of voluntary liquidations under different assumptions about the SAC borrowers' share of owners.

\begin{tabular}{llllll}
\hline Year & Actual & \multicolumn{4}{l}{ Predicted probability exceeded $83 \%$ when SAC borrower asset shares were } \\
\cline { 3 - 6 } & & Equal to actual value & All greater than $1 / 3$ & All between $1 / 4$ and $1 / 3$ & All less than $1 / 4$ \\
\hline 1934 & 2 & 0 & 0 & 0 & 0 \\
1935 & 9 & 0 & 0 & 0 & 0 \\
1936 & 36 & 4 & 1 & 4 & 4 \\
1937 & 82 & 12 & 3 & 4 & 14 \\
1938 & 69 & 21 & 6 & 16 & 32 \\
1939 & 149 & 184 & 39 & 93 & 185 \\
1940 & 4 & 130 & 49 & 230 & 374 \\
Total & 351 & 351 & 98 &
\end{tabular}

Notes. Probabilities of voluntary liquidations are based on coefficients from specification 3 in Table 2 and the baseline hazards and values for each observation. When the predicted probability reached $83 \%$ or higher in the predictions, we assumed the firm liquidated.

149 in 1939. As a benchmark for our counterfactual exercise, the second column presents the predicted pattern of voluntary liquidations over time using the predicted probabilities of liquidation derived from the estimated coefficients in specification 3 in Table 2 in conjunction with the actual values of the correlates and the baseline probabilities for each observation. We assigned voluntary liquidation status to each B\&L when its predicted probability of liquidation rose to or above $83 \%{ }^{35}$ This threshold was chosen because at that threshold the model predicts the same number of voluntary liquidations as the number that actually occurred. The time pattern of these predictions was more back-loaded than the actual distribution as there are no predicted liquidations before 1936, a higher peak than the actual peak in 1939, and more predicted liquidations in 1940.

The remaining three columns in Table 3 show the results of this counterfactual exercise. We present the total number and time pattern of predicted voluntary liquidations using the 83 percent threshold for entering predicted voluntary liquidation under different counterfactual values of the SAC borrowers' share of membership. If all firms had had SAC Borrower Shares greater than one-third, the total number of predicted liquidations would have been cut sharply (from 351-98), and the peak of these liquidations would have been delayed (from 1939 to 1940). Had the SAC shares for all associations been between one-third and one-fourth, on the other hand, the predicted number of liquidations would have been 230 , roughly two-thirds of the actual number liquidations. Had all firms had SAC shares been below one-fourth, the number of predicted liquidations increases to a number above the actual number of liquidations. These patterns illustrate the powerful predicted negative impact that higher shares of borrowing members with SAC loans had on the likelihood and timing of voluntary liquidation among New Jersey B\&Ls.

In the middle panel of Table 2 we show the magnitude of the impacts of all the remaining variables in Specification 3. Because these variables are continuous, we show the effect on the probability of liquidation of a one-standard deviation change in each correlate holding all others at their sample values. We also show the effects on the predicted probability of the change in the mean of each variable between 1934 and 1939. The standard deviations for the sample and the mean values for 1934 and 1939 are shown in Table 1.

Because the SAC mortgage membership share variables are dummy variables, the changes above when we assign all observations to have SAC shares above one-third are not directly comparable to one-standard deviation changes for continuous variables. To

\footnotetext{
35 In results not reported in the paper (available upon request) we do the same exercise using the actual probability of liquidation predicted for each firm at the time of liquidation, instead of the $83 \%$ rule for all firms, and the results are very similar to the ones reported in the paper.
}

allow comparisons of the magnitude of the impact of the SAC borrower share to the impact of other factors, we have re-estimated the model with the share of members with SAC mortgages, which is continuous, as the dependent variable. The coefficients of the SAC share continuous variable in Table 2 are statistically significant and negative in specifications 4,5 , and 6 in Table 2 . The effect of a one-standard deviation increase of 0.129 in the SAC share leads to the reduction in the predicted liquidation probability of 5.6 percentage points from $16 \%$ to $10.4 \%$. Between 1934 and 1939 the mean SAC share fell by 10.3 percentage points from $26.3 \%$ to $16 \%$ percent. Such a decline would have been associated with a rise in the predicted liquidation probability of 5.6 percentage points from $16 \%$ to $21.6 \%$.

Only three correlates in Table 2 have impacts on the predicted probability of liquidation larger or comparable in size to the SAC borrower share of membership. First, the 38 percent decrease in the average size of B\&Ls fell between 1934 and 1939 (Table 1) increased the predicted probability of liquidation by 4.2 percentage points (Table 2). Second, the decrease from $5.1 \%$ to $2.6 \%$ in the average share of arrears in B\&L lowered the probability of liquidation by -2.2 percentage points. Finally, between 1934 and 1939 the share of assets in real estate owned rose from $21.5 \%$ to $37.6 \%$ of assets (Table 1), implying a 14.3 percentage point increase in the probability of liquidation in Table 2. 36

\section{Discussion}

Building and Loan associations had been the nation's leading source of residential mortgage finance for decades prior to the Great Depression. In the 1930s, however, severely distressed B\&Ls continued to operate long after they were viable lending institutions because their borrowing members had strong incentives to oppose the voluntary liquidation of their association until their own loans had been repaid. By delaying liquidation, they had a better chance of paying off their loans with shares valued at full book value and avoiding the losses associated with liquidation. Borrowers could successfully postpone liquidation over the objections of non-borrowing members, moreover, because B\&L case law

\footnotetext{
36 The nonlinear nature of the exponential function underlying the Cox hazard model leads to differences in the magnitudes of changes in the probability of liquidation associated with changes in correlates at different points in the distribution. In the text, the comparisons are based on the average of the marginal differences associated with a change for each observation. An alternative method is to calculate the marginal effect when the predicted probability is evaluated at a point associated with the means for all of the correlates. This method also tells the same qualitative story as in the text. The predicted probability at of liquidation evaluated at the means is $5.1 \%$. A one-standard deviation increase in the dummy for a SAC member share over one-third is associated with a -1.2 drop in the liquidation probability. The only larger effects of a one-standard deviation rise are for the real estate share of assets at 5.3 , the size of the $B \& L$ at -2.1 and the arrears share of assets at 1.7. The OSD effect for installment dues was the same size at -1.2 .
} 
required two-thirds of the voting members of a B\&L to approve a resolution of voluntary liquidation. Using annual balance sheet and membership data we estimate that voting power of borrowing members delayed the liquidation of distressed B\&L associations in New Jersey by an average of about one year between 1936 and 1940.

For nearly one hundred years before 1930 building and loans had been effective in bringing small investors and borrowers together to finance housing. Their popularity reached its peak during the 1920s and during this expansion B\&Ls began to offer its nonborrowing members the same liquidity as a bank deposit along with relatively high returns. These relaxed withdrawal policies were beyond both the capacity and the contractual obligation of B\&Ls, however, as was dramatically revealed during the severe housing crisis of the 1930s. B\&Ls were intentionally designed to fund long-term, illiquid loans and empowered to preserve this function when under severe distress by suspending withdrawals indefinitely and delaying liquidation until it was approved by a super majority of the members. We have seen that non-borrowing members were caught in frozen associations because of these contractual features and forced to choose whether to hold claims on risky portfolios of distressed mortgage loans and foreclosed real estate longer than desired, or sell shares off at deep discounts.

These newfound problems contributed to the demise of B\&Ls as mortgage lending institutions. The great majority of the 12,000 B\&Ls operating in the U.S. in 1930 were organized under the contractual arrangements examined here, but by 1941 the number of these traditional B\&Ls had fallen to only 3100. By then a new S\&L industry, comprised of 3000 converted B\&Ls and 600 new federally chartered institutions, held 80 percent of thrift assets and the S\&L share then increased to over 90 percent by $1950 .^{37}$ In two short, tumultuous decades the new S\&L model had replaced the traditional B\&L as the nation's largest source of home mortgage loans.

The illiquidity and delayed resolution of B\&L investments examined here were likely to have played an important role in their rapid displacement because the new Savings \& Loan model offered financial products with greater liquidity, simplicity and convenience than the traditional SAC-based contracts. Most important for non-borrowers were "optional share accounts" that permitted both investments and withdrawals at any time without the fines or forfeitures of dividends that accompanied B\&L withdrawals. ${ }^{38}$ In the event of severe distress, moreover, the new S\&L model incorporated a resolution mechanism that was triggered by a regulatory authority, rather than a vote of members, and an insurance program that that protected investments at their book value during and after liquidation. ${ }^{39}$

\footnotetext{
37 By 1940 the S\&L industry was comprised of converted state-chartered B\&Ls and 600 new federally-chartered S\&Ls (Snowden, 2003).

38 S\&L borrowers, meanwhile took out familiar, modern "direct reduction" mortgage loans in which monthly payments of principal reduced the outstanding loan balance rather than being used to purchase B\&L shares that were placed in a sinking fund. Ewalt $(1962,171)$ discusses the development of the optional S\&L account and its comparison to the B\&L savings plan. For additional discussion of the shifts toward S\&Ls and the dissolution process of B\&Ls, see Rose (2014), Rose and Snowden (2013), and Snowden (2003, 2010).

39 By 1935 the Federal Home Loan Bank system and the Federal Savings and Loan Insurance Corporation provided a regulatory mechanism that could initiate, manage and complete the resolution of distressed institutions. Their authority to do so was explicit and unambiguous for members of the new Federally-chartered Savings \& Loans that held $50 \%$ of thrift assets and state-chartered members of the FHLB and FSLIC that held another $30 \%$ of industry assets. In both cases the FHLB Board had the power to declare an association insolvent and to appoint the FSLIC as receiver. In these cases the FSLIC not only settled the insurance claims of individual S\&L members, but also determined whether the association should be liquidated, merged with another institution or continue to operate under FSLIC conservatorship (Bodfish and Theobald, 1938).
}

The resolution mechanism built into the new S\&L industry was still in place and tested seriously for the first time in the 1980s when widespread distress swept through thrift industry during the Savings \& Loan crisis. Although the FHLB and FSLIC had by then appeared to have eliminated the types of prolonged and costly resolutions experienced by B\&Ls fifty years earlier, market participants and the regulators were once again surprised. This time a primary source of delay in resolving the crisis was the forbearance of regulators who had the authority to resolve distress S\&Ls in a speedier and more efficient manner. The costs of delay were also distributed differently in the two episodes-to non-borrowing B\&L members in the 1930s but to the general taxpayer in the 1980s once the FSLIC fund was exhausted in 1986 and the Resolution Trust Corporation was created to complete its work.

Like the demise of the B\&Ls in the 1930s, the delays and costs of resolving S\&L distress in the 1980s contributed to a significant and lasting reduction in the importance of S\&Ls within the residential home mortgage market. ${ }^{40}$ This development, in turn, contributed to the emergence and popularity of new mortgage lending arrangements in the 2000s-private label mortgage-backed securitization and the use of junior liens as augments to first mortgage loans. ${ }^{41}$ Both lending channels relied heavily on third-party loan servicing and the capabilities of these arrangements as resolution mechanisms were almost immediately tested as rates of defaults and foreclosures spiked in 2007. Recent evidence shows that renegotiations or modifications of distressed mortgages within these market segments occurred at lower rates or with longer delays than in the market in general (Agarwal et al., 2011, 2014; Been et al., 2012; Bond et al., 2015). These results indicate that the resolution activities of third party servicers missed opportunities to implement modifications that would have benefitted both borrower and lender and reduced the costs of resolving the crisis. A variety of explanations have been offered for the poor performance: inadequate capitalization and compensation to finance resolution activities; moral hazards or conflicts of interest that reduced a servicer's incentives to modify first loans they do not own; and inadequate procedural and legal direction regarding resolution activities (Cordell et al., 2008; Goodman, 2011a, 2011b). ${ }^{42}$ As with B\&Ls, each of these impediments resulted from contractual elements were built into lending arrangements before a crisis, but not clearly understood until exposed to distress.

The B\&L case examined here, therefore, represents the first of three episodes within the last century in which the resolution mechanism built into a previously important residential mortgage

\footnotetext{
40 By 1990 the S\&L share of single family mortgages had fallen to $30 \%$ from $53 \%$ See Kane (1989). The Federal Deposit Insurance Corporation (FDIC) website offers a detailed chronology of the events with a large list of references at http://www.fdic. gov/bank/historical/s\&l/.

41 The Housing Finance Policy Center $(2015,8)$ reports that private label MBS loans grew from $10 \%$ of first lien originations in 2000 to $40 \%$ in both in 2005 and 2006 . Lee et al (2012) find that up to $45 \%$ of home purchases in coastal and "bubble" markets used junior mortgages and that total second lien originations tripled in volume between 2001 and 2006. Been et al. (2012) estimate that roughly 25\% of all mortgaged homes carried second liens between 2004 and 2009. Goodman et al (2010) connect these two trends by finding that junior liens were present for more than one-half of first liens that were placed behind private label MBS. Third party servicing had been used extensively before the 1990s, but primarily as adjuncts to the FHA and VA loan programs and the mortgage-backed securities businesses of Fannie Mae and Freddie Mac. Third party servicing is important when junior liens are present because banks, and especially large banks, originate and retain ownership of most second liens. The bank becomes a third party servicer when the first liens are then sold.

42 Since 2007, there has been retrenchment in the use of private label MBS and "piggy back" first and second loans (see Housing Policy Finance Center, 2015; Prevost, 2014), substantial compositional change in the third party loan servicing industry (Mortgage Bankers Association et al., 2015) and proposals for reform of the industry from Congress, industry professionals and academics (see Mayer et al., 2009; Morgensen, 2010; Goodman, 2011a, 2011b).
} 
Table 4

Results from parametric survival models of hazard of voluntary liquidation of New Jersey B\&Ls, 1934-1940.

\begin{tabular}{|c|c|c|c|c|}
\hline & \multicolumn{2}{|c|}{ Exponential model } & \multicolumn{2}{|c|}{ Weibull model } \\
\hline & (I) & (II) & (III) & (IV) \\
\hline SAC borrowers are between one-fourth and one-third of members & $\begin{array}{l}-0.5824^{* *} \\
(0.2297)\end{array}$ & & $\begin{array}{l}-0.7805^{* * *} \\
(0.2347)\end{array}$ & \\
\hline SAC borrowers are more than one-third of members & $\begin{array}{l}-1.0992^{* * * *} \\
(0.3163)\end{array}$ & & $\begin{array}{l}-1.2604^{* * *} \\
(0.2628)\end{array}$ & \\
\hline SAC borrowers' share of members & & $\begin{array}{l}-3.3495^{* * *} \\
(0.8812)\end{array}$ & & $\begin{array}{l}-3.8629 * * * \\
(1.1001)\end{array}$ \\
\hline Balance sheet controls & Yes & Yes & Yes & Yes \\
\hline 1930 Characteristics controls & Yes & Yes & Yes & Yes \\
\hline County controls & Yes & Yes & Yes & Yes \\
\hline
\end{tabular}

Notes. The sample is confined to B\&Ls that stayed open or voluntarily liquidated. There are 8449 observations across time and B\&L.

* $p<0.05$

Table 5

Results in sample including all B\&Ls and treating only voluntary liquidations as liquidations.

\begin{tabular}{|c|c|c|c|c|c|c|}
\hline & \multicolumn{6}{|c|}{ Specification } \\
\hline & \multicolumn{3}{|c|}{ Treating only voluntary liquidations as liquidations } & \multicolumn{3}{|c|}{ Treating all closures as voluntary liquidations } \\
\hline & 1 & 2 & 3 & 4 & 5 & 6 \\
\hline SAC borrowers are more than one-third of members & $\begin{array}{l}-1.3333^{*} \\
(0.1895)\end{array}$ & $\begin{array}{l}-0.8824^{*} \\
(0.2752)\end{array}$ & $\begin{array}{l}-0.7108^{*} \\
(0.2595)\end{array}$ & $\begin{array}{l}-1.0845^{*} \\
(0.1868)\end{array}$ & $\begin{array}{l}-0.6432 * \\
(0.2349)\end{array}$ & $\begin{array}{l}-0.4858^{*} \\
(0.2578)\end{array}$ \\
\hline SAC borrowers are between one-fourth and one-third of members & $\begin{array}{l}-0.9453^{*} \\
(0.2134)\end{array}$ & $\begin{array}{l}-0.4143^{*} \\
(0.1711)\end{array}$ & $\begin{array}{c}-0.2708 \\
(0.1880)\end{array}$ & $\begin{array}{l}-0.8286^{*} \\
(0.1366)\end{array}$ & $\begin{array}{l}-0.3415^{*} \\
(0.1294)\end{array}$ & $\begin{array}{l}-0.2100 \\
(0.1463)\end{array}$ \\
\hline DRC borrowers' share of members & $\begin{array}{l}-3.6216^{*} \\
(2.0600)\end{array}$ & $\begin{array}{l}1.4801^{*} \\
(0.6926)\end{array}$ & $\begin{array}{l}1.5506^{*} \\
(0.8326)\end{array}$ & $\begin{array}{l}-1.2139 \\
(1.7608)\end{array}$ & $\begin{array}{l}2.6017 * \\
(0.7257)\end{array}$ & $\begin{array}{l}2.4632 * \\
(0.9263)\end{array}$ \\
\hline Natural log of (total assets) & & $\begin{array}{l}-0.6937^{*} \\
(0.0608)\end{array}$ & $\begin{array}{l}-0.6830^{*} \\
(0.1369)\end{array}$ & & $\begin{array}{l}-0.3618^{*} \\
(0.0834)\end{array}$ & $\begin{array}{l}-0.2600^{*} \\
(0.1305)\end{array}$ \\
\hline \multicolumn{7}{|l|}{ Share of assets in } \\
\hline Real estate owned & & $\begin{array}{l}3.5502^{*} \\
(0.7053)\end{array}$ & $\begin{array}{l}3.5205^{*} \\
(0.6448)\end{array}$ & & $\begin{array}{l}3.3023^{*} \\
(0.5116)\end{array}$ & $\begin{array}{l}3.1455^{*} \\
(0.4735)\end{array}$ \\
\hline Arrears & & $\begin{array}{l}6.6687^{*} \\
(1.1717)\end{array}$ & $\begin{array}{l}5.7404^{*} \\
(1.2514)\end{array}$ & & $\begin{array}{l}6.1341^{*} \\
(1.0803)\end{array}$ & $\begin{array}{l}5.0757^{*} \\
(0.9157)\end{array}$ \\
\hline Cash on hand & & $\begin{array}{l}-3.0211^{*} \\
(1.1278)\end{array}$ & $\begin{array}{l}-2.9473^{*} \\
(0.6194)\end{array}$ & & $\begin{array}{l}0.7821 \\
(1.1853)\end{array}$ & $\begin{array}{l}1.2577 \\
(1.1898)\end{array}$ \\
\hline \multicolumn{7}{|l|}{ Share of liabilities in } \\
\hline Installment shares & & $\begin{array}{l}-1.0602^{*} \\
(0.4747)\end{array}$ & $\begin{array}{l}-1.2906^{*} \\
(0.5500)\end{array}$ & & $\begin{array}{l}-1.6718^{*} \\
(0.4309)\end{array}$ & $\begin{array}{l}-1.8504^{*} \\
(0.4561)\end{array}$ \\
\hline Paid-up shares & & $\begin{array}{l}-0.8826 \\
(0.7832)\end{array}$ & $\begin{array}{l}-1.1584^{*} \\
(0.6119)\end{array}$ & & $\begin{array}{c}-1.1593^{*} \\
(0.5502)\end{array}$ & $\begin{array}{l}-1.2042 * \\
(0.5982)\end{array}$ \\
\hline Unapportioned profits & & $\begin{array}{l}2.6491^{*} \\
(0.9743)\end{array}$ & $\begin{array}{l}2.2835^{*} \\
(1.0841)\end{array}$ & & $\begin{array}{l}-0.5063 \\
(0.6634)\end{array}$ & $\begin{array}{l}-0.7061 \\
(0.7483)\end{array}$ \\
\hline \multicolumn{7}{|l|}{ County data } \\
\hline Retail sales per capita & & & $\begin{array}{l}0.0006 \\
(0.0024)\end{array}$ & & & $\begin{array}{l}-0.0007 \\
(0.0019)\end{array}$ \\
\hline Federal tax returns filed per capita & & & $\begin{array}{l}5.8871 \\
(4.7402)\end{array}$ & & & $\begin{array}{l}\text { 7.3913* } \\
(3.1556)\end{array}$ \\
\hline Value of HOLC loans per household & & & $\begin{array}{l}0.0003 \\
(0.0010)\end{array}$ & & & $\begin{array}{l}-0.0002 \\
(0.0005)\end{array}$ \\
\hline \multicolumn{7}{|l|}{ Information from 1930} \\
\hline Natural log of (total assets) & & & $\begin{array}{l}0.0168 \\
(0.1743)\end{array}$ & & & $\begin{array}{l}-0.0597 \\
(0.1341)\end{array}$ \\
\hline \multicolumn{7}{|l|}{ Share of assets in } \\
\hline Real estate owned & & & $\begin{array}{l}0.8612 * \\
(0.2645)\end{array}$ & & & $\begin{array}{l}0.5040 \\
(0.5499)\end{array}$ \\
\hline Arrears & & & $\begin{array}{l}7.5735 \\
(4.8602)\end{array}$ & & & $\begin{array}{l}10.4437^{*} \\
(2.0724)\end{array}$ \\
\hline Cash on hand & & & $\begin{array}{l}3.8157^{*} \\
(1.9137)\end{array}$ & & & $\begin{array}{l}3.2651^{*} \\
(1.5587)\end{array}$ \\
\hline \multicolumn{7}{|l|}{ Share of liabilities in } \\
\hline Installment shares & & & $\begin{array}{l}0.4623 \\
(0.7679)\end{array}$ & & & $\begin{array}{l}0.5504^{*} \\
(0.2702)\end{array}$ \\
\hline Paid-up shares & & & $\begin{array}{l}0.9400 * \\
(0.3162)\end{array}$ & & & $\begin{array}{l}0.2510 \\
(0.8018)\end{array}$ \\
\hline Unapportioned profits & & & $\begin{array}{r}-0.2730 \\
(5.6836)\end{array}$ & & & $\begin{array}{l}10.3204^{*} \\
(3.8986)\end{array}$ \\
\hline
\end{tabular}

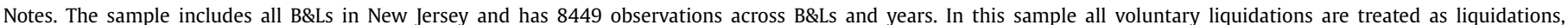
while all survivors and the firms that were merged, acquired, closed by the state or closed for other reasons are treated as nonliquidations.

${ }^{*} p<0.05$ 
Table 6

Multinomial estimation for voluntary liquidations, mergers/acquisitions, state liquidations, and other liquidations.

\begin{tabular}{|c|c|c|c|c|c|c|c|c|}
\hline & \multicolumn{2}{|c|}{ Voluntary liquidations } & \multicolumn{2}{|c|}{ Acquisitions and mergers } & \multicolumn{2}{|c|}{ State interventions } & \multicolumn{2}{|l|}{ Others } \\
\hline & Coeff. & Z-score & Coeff. & Z-score & Coeff. & Z-score & Coeff. & Z-score \\
\hline SAC borrowers are more than one-third of members & -1.405 & -4.71 & -0.639 & -2.06 & -1.051 & -1.35 & -0.615 & -1.00 \\
\hline SAC borrowers are between one-fourth and one-third of members & -0.748 & -3.37 & -0.249 & -0.90 & -0.568 & -0.87 & -1.024 & -2.06 \\
\hline DRC borrowers' share of members & 0.122 & 0.10 & 3.502 & 2.09 & -9.566 & -1.82 & 2.999 & 1.48 \\
\hline Natural log of (total assets) & -1.391 & -7.14 & -0.824 & -3.67 & 0.401 & 0.65 & 0.595 & 1.88 \\
\hline \multicolumn{9}{|l|}{ Share of assets in } \\
\hline Real estate owned & 4.093 & 5.99 & 0.703 & 0.56 & 7.798 & 6.63 & 0.741 & 0.76 \\
\hline Arrears & 9.018 & 4.49 & 2.983 & 2.59 & 13.548 & 6.48 & -3.597 & -0.74 \\
\hline Cash on hand & 4.954 & 4.02 & -1.797 & -0.82 & 11.736 & 1.17 & 12.126 & 3.90 \\
\hline \multicolumn{9}{|l|}{ Share of liabilities in } \\
\hline Installment shares & -1.872 & -2.50 & -2.593 & -1.56 & -1.552 & -0.85 & -1.388 & -0.69 \\
\hline Paid-up shares & -1.423 & -2.00 & -0.592 & -1.02 & -5.113 & -4.29 & -3.864 & -3.03 \\
\hline Unapportioned profits & 3.261 & 3.21 & -7.493 & -2.75 & -1.594 & -0.70 & -3.753 & -1.19 \\
\hline \multicolumn{9}{|l|}{ County data } \\
\hline Retail sales per capita & 0.002 & 0.70 & 0.001 & 0.47 & -0.007 & -1.13 & -0.003 & -1.01 \\
\hline Federal tax returns filed per capita & -22.084 & -5.30 & -6.234 & -1.25 & -13.128 & -1.63 & -18.835 & -2.84 \\
\hline Value of HOLC loans per household & -0.00001 & -0.01 & 0.0003 & 0.73 & -0.124 & -0.26 & -10.082 & -5.71 \\
\hline \multicolumn{9}{|l|}{ Information from 1930} \\
\hline Natural log of (total assets) & 0.587 & 2.68 & 0.420 & 2.44 & -0.167 & -0.27 & -0.031 & -0.10 \\
\hline \multicolumn{9}{|l|}{ Share of assets in } \\
\hline Real estate owned & 1.936 & 2.79 & -1.771 & -0.65 & 0.673 & 0.31 & 7.314 & 5.19 \\
\hline Arrears & 6.573 & 1.08 & -3.343 & -0.32 & 21.514 & 1.48 & 16.389 & 1.07 \\
\hline Cash on hand & 3.935 & 1.73 & 1.821 & 0.38 & 1.927 & 0.22 & -9.621 & -0.90 \\
\hline \multicolumn{9}{|l|}{ Share of liabilities in } \\
\hline Installment shares & 1.510 & 2.83 & 1.785 & 3.63 & -4.643 & -2.53 & 0.825 & 1.24 \\
\hline Paid-up shares & 2.639 & 2.63 & 3.399 & 1.72 & -2.370 & -1.24 & 1.131 & 0.42 \\
\hline Unapportioned profits & 4.945 & 0.97 & 29.931 & 3.03 & 22.083 & 2.05 & 19.141 & 2.65 \\
\hline $\log ($ duration $)$ & 2.143 & 4.83 & 0.757 & 2.18 & 3.793 & 2.10 & 5.435 & 6.43 \\
\hline Constant & 2.080 & 0.92 & -0.569 & -0.28 & -8.925 & -1.62 & -17.346 & -4.88 \\
\hline
\end{tabular}

Notes. The sample includes all B\&Ls in New Jersey and has 8449 observations across B\&Ls,

lending channel performed poorly and with great impact during severe and widespread distress. In each case the delays and costs associated with resolution have been severe enough to generate new innovations in contracts and lending arrangements that incorporated resolution mechanisms that were, once again, untested by crisis.

\section{Appendix A}

\section{Robustness checks}

The Cox survival model has the advantage of not having to specify a functional form for the baseline survival function, but this flexibility comes at the cost of assuming that the effect of the covariates on the hazard is proportional. A way to relax the assumption is to impose a parametric distribution on the survival function, and to estimate a fully parametric survival model via maximum likelihood. In Table 4 we present the results of estimating the model using both the Exponential (Columns 1 and 2) and the Weibull (Columns 3 and 4) distributions for the baseline survival function. The results show that the effect of the share of SAC members remains negative, statistically significant and similar in magnitude to our earlier estimates. We have also estimated, but do not report here, linear probability models with B\&L-specific and timeby-county-specific fixed effects and a random effects Probit model of voluntary liquidation. The estimated effects of the SAC borrower share of members in all of these models are qualitatively similar to those from our preferred Cox model specification.

The estimates reported in the last section also rely on our decision to exclude from the sample the B\&Ls that exited the industry during the same period through a mechanism other than voluntary liquidation. The rationale for trimming the sample was to focus on the decision whether to voluntarily liquidate or continue operations because we have clear understanding of the incentives driv- ing the agents who made this decision (the members of the $\mathrm{B} \& \mathrm{~L}$ ). We do not have clear predictions about the decisions to exit by other means because each of them required the approval of agents outside the B\&L. ${ }^{43}$

Here we follow two strategies to evaluate the SAC borrower effect in a model that allows for all types of exits. First, in Table 5 we present the results when the sample includes all B\&Ls, and we treat as liquidations only the voluntary ones (Columns 1,2 and 3) or we focus on all closures (Columns 4,5 and 6). The results are very similar in terms of the estimated value of the coefficient and its level of statistical significance. Second, in Table 6 we present the results from the estimation of a multinomial Logit model that includes all B\&Ls and examines the probability of all categories of liquidations together: voluntary liquidations, acquisitions and mergers, state interventions, and other. The qualitative results are the same for the voluntary liquidations for the SAC share variables. The SAC share is also negatively related to the probability of the other types of closures, but the only coefficient that is statistically significant when the other types of closures are considered is the SAC share greater than one-third for acquisitions and mergers. As for other variables, the presence of more high-income federal taxpayers likely reduced the probability of voluntary liquidation in this estimation. The HOLC purchase and refinance program had a strong negative relationship with other types of liquidations.

A final concern about the robustness of the survival model specification that we reported earlier is that we have imposed discrete measures of the share of SAC members in order to capture the thresholds that were critical in the vote to liquidate. This modeling decision could influence the estimates improperly if the SAC member share, which declined throughout the 1930s, was corre-

\footnotetext{
43 For example, mergers required agreement by the members of both associations, reorganizations were mediated by trustees, and state closures were directed by regulators.
} 
lated over time with some other determinant of liquidation and this was not captured correctly by the survival model structure. We address this concern here by investigating whether there is evidence of a discontinuity around the cutoff of one third in the impact of the SAC borrowing member share within a linear probability model in which the share of SAC members enters as a continuous variable.

Our approach here has the flavor of a regression discontinuity design (RDD), but it is not strictly an RDD because there are two sources of noise in the cutoff for the share of SAC members. First, there is measurement error in the share of SAC members because, as explained above, it is computed using the share of SAC loans and the number of total members. Second, even though the requirement for voluntary liquidation is the vote of $2 / 3$ of the members present in a meeting called for that purpose, the attendance at the meeting was voluntary. In this sense, a share close to $1 / 3$ of SAC members could still block the voluntary liquidation if some of the members did not attend the meeting. This is particularly relevant because, as discussed before, SAC members had the most interest in attending the meeting.

To evaluate the discontinuity in the probability of liquidation around the cutoff of the share of SAC members, we provide graphical and regression analysis similar to the approach suggested by Imbens and Lemieux (2008) for the case of the RDD. The idea is to limit the sample to those observations close to the cutoff, and to look at the discrete change in the outcome variable at the cutoff. The use of a sample within a smaller interval provides a way to compare observations above and below the cutoff that are more likely to be similar.

In the graphical analysis, we limit the sample to the observations with a share of SAC members within 20 percentage points below or above the cutoff. In the top panel of Fig. 1 we present the average probability of voluntary liquidation (residualized of the other control variables) for each of the 40 one-percentage-point intervals of the share of SAC members. In the graph we also report the predicted values of a regressions of the residual of the probability of voluntary liquidation on the share of SAC members for the samples before and after the cutoff.

The graph shows a discontinuity in the probability of voluntary liquidation around the cutoff. However, it is also possible to notice in the graph the effect of the measurement error in the probability of liquidation of firms that are very close to the $1 / 3$ cutoff. In particular, the probability of liquidation for the observations that are just to the left of the cutoff (the average for the observations in the interval one percentage point below the cutoff) is not very different to the probability of liquidation for the observations just above the cutoff.

One potential concern with this graphical analysis is that the discontinuity in the probability of liquidation around the cutoff could be related to a discontinuity in the values of other control variables. To overcome this concern, we examine whether the voluntary liquidation probability predicted from a regression of the liquidation on the control variables (excluding any function of the SAC member share) has a discontinuity around the SAC member share cutoff. The bottom panel of Fig. 1 shows that the voluntary liquidation probability predicted for the covariates does not exhibit a discontinuity around the cutoff.

We also use regression analysis to confirm the results suggested by the graphical analysis. We estimate linear probability models of the voluntary liquidation on an indicator variable for the cutoff of $1 / 3$ of the share of SAC members, as well as controlling for the continuous share of SAC members, allowing the latter to have different slopes before and after the cutoff. We estimate three different specifications of this model; first, without any controls; secondly, we include B\&L-specific and time-by-county-specific fixed effects; and in a third specification, we also include the time-
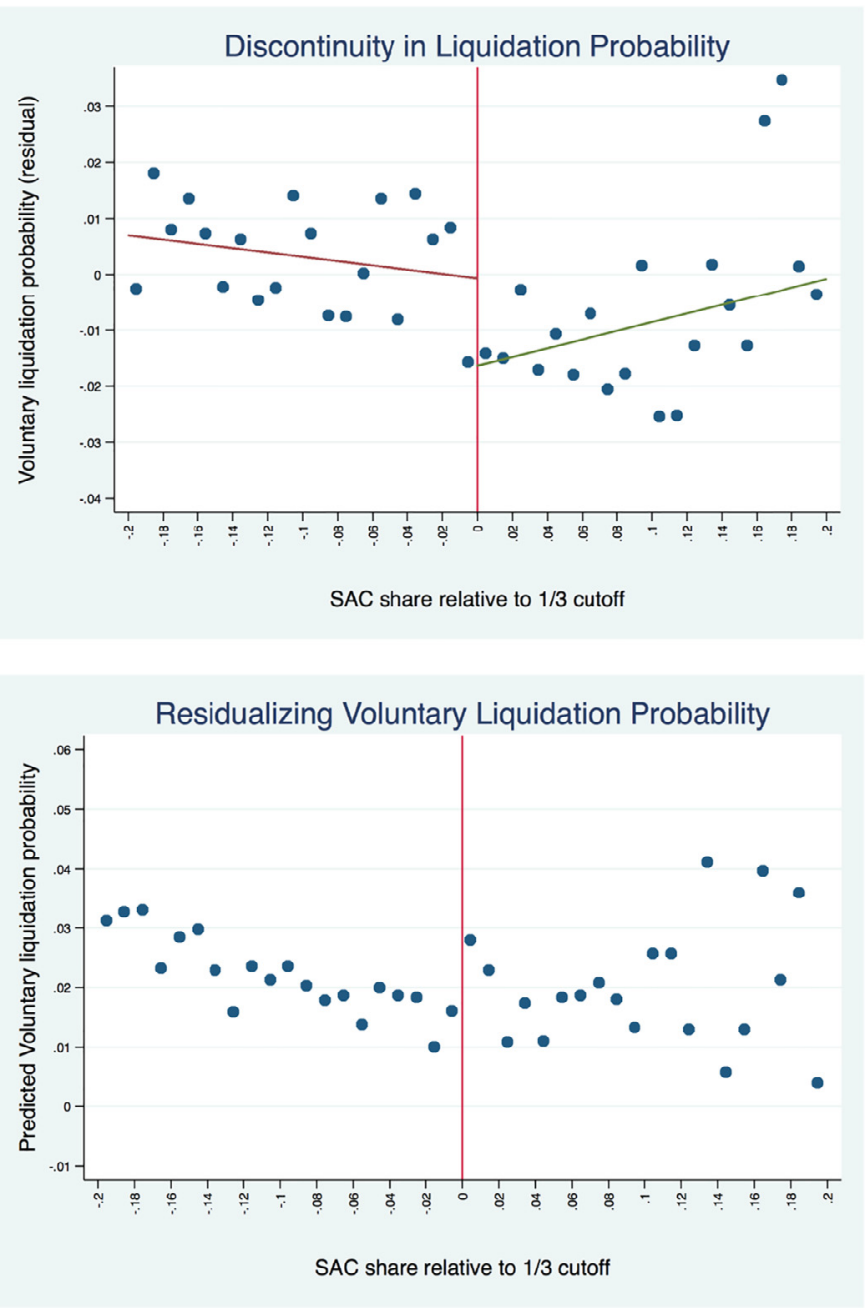

Fig. 1. Regression analysis of the effect of share of SAC member in an interval around the cutoff

Figure 1.1: Discontinuity in the residual of the probability of liquidation (residual from a regression of the probability of liquidation on control variables and B\&L and time-by-county fixed effects), around the cutoff of $1 / 3$ SAC member share (normalized to zero).

Figure 1.2: Discontinuity in the predicted liquidation probability from a regression of the probability of liquidation on control variables and B\&L and time-by-county fixed effects, around the cutoff of 1/3 SAC member share (normalized to zero).

variant balance sheet information for the firms as controls. Formally, the third specification, which includes all the controls, is:

$$
\begin{aligned}
y_{i c t}= & \alpha_{i}+\beta 1\left(S A C_{i c t}>1 / 3\right)+\gamma_{1} S A C_{i c t}+\gamma_{2} S A C_{i c t} * 1\left(S A C_{i c t}>1 / 3\right) \\
& +\mathrm{F}_{i c t} \phi+\delta_{c t}+\varepsilon_{i c t}
\end{aligned}
$$

where $y_{i c t}$ is an indicator function for voluntary liquidation of firm $i$ in county $c$ at time $t$. $S A C_{i c t}$ is a the share of SAC members, $1\left(S A C_{i c t}>1 / 3\right)$ is an indicator function that takes the value of one if the share of SAC members is higher than the cutoff. The coefficient of interest is $\beta$, which represents the discontinuity in the probability of voluntary liquidation at the cutoff. $\gamma_{1}$ is the coefficient for the slope of the effect of SAC share before the cutoff, and $\gamma_{2}$ is a coefficient for the difference in the slope of SAC member share after the cutoff. As before, $\mathrm{F}$ is a vector of time-variant balance sheet firm characteristics. Finally, $\alpha_{i}$ is a fixed effect for firm $i, \delta_{c t}$ are is a fixed effect for county $c$ in year $t$, and $\varepsilon_{i c t}$ is the error term.

Table 7 presents the results for the estimation of these regression models, limiting the sample to those observations with SAC member shares within different intervals around the cutoff. The results confirm the discontinuity in the probability of 
Table 7

Regression analysis of the effect of share of SAC member in an interval around the cutoff.

\begin{tabular}{|c|c|c|c|c|c|c|}
\hline \multirow[b]{2}{*}{ SACmem_Block } & \multicolumn{3}{|c|}{20 p.p. interval $[0.133,0.533]$} & \multicolumn{3}{|c|}{30 p.p. interval $[0.033,0.633]$} \\
\hline & $\begin{array}{l}(1) \\
-0.0845^{*} \\
(0.0311)\end{array}$ & $\begin{array}{l}(2) \\
-0.1525^{*} \\
(0.0368)\end{array}$ & $\begin{array}{l}(3) \\
-0.1527^{*} \\
(0.0353)\end{array}$ & $\begin{array}{l}(4) \\
-0.1480^{*} \\
(0.0358)\end{array}$ & $\begin{array}{l}(5) \\
-0.1352^{*} \\
(0.0391)\end{array}$ & $\begin{array}{l}(6) \\
-0.1354 * \\
(0.0346)\end{array}$ \\
\hline B\&L fixed effects & No & Yes & Yes & No & Yes & Yes \\
\hline Time-by-county FE & No & Yes & Yes & No & Yes & Yes \\
\hline Other controls & No & No & Yes & No & No & Yes \\
\hline Observations & 5956 & 5956 & 5956 & 7983 & 7983 & 7983 \\
\hline
\end{tabular}

Notes. Estimates from Eq. (2) with different structure of controls reported. The sample is confined to B\&Ls that stayed open or voluntarily liquidated. The sample only uses the observations in the interval from the original sample of 8449 observations across time and B\&L. The first three columns use a 20 percentage point interval around the cutoff, while the next three columns use a 30 percentage point interval around the cutoff.

${ }^{*} p<0.05$

voluntary liquidation around the cutoff. The first three columns of Table 7 present the results when we use an interval of 20 percentage points on each side of the cutoff, the same interval used in the graphical analysis. All these estimates show that there is a statistically significant decrease in the probability of voluntary liquidation at the cutoff of the share of SAC members. In Column 1 we present the results when we do not control for any fixed effects or balance sheet information of the firms, and the magnitude of the effect implies that the probability of failure is about 8.5 percentage points lower when the share of SAC members is above the cutoff. When we control for time-by-county and firm-specific fixed effects in Column 2, the point estimate for the magnitude increases to about 15 percentage points, and it remains virtually unchanged when we include all the control variables (fixed effects and balance sheet information) in Column 3. Columns 4-6 show the results when we include observations within an interval of 30 percentage points above or below the cutoff. Again, there is a statistically significant decrease in the probability of voluntary liquidation at the cutoff of the share of SAC members. The estimated coefficient implies a 15 percentage-point decrease in the probability of liquidation when we use the specification without controls or fixed effects (Column 4), and around 13.5 percentage points when we use only fixed effects (Column 5) or the full set of controls (Column 6). Overall, the graphical analysis shows that there is a discontinuity around the cutoff of $1 / 3$, and the regression models indicate that the decrease in the probability of liquidation associated with a SAC member share above $1 / 3$ is estimated to be about 14 percentage points Table 7.

\section{References}

Agarwal, S., Amromin, G., Ben-David, I., Chomsisengphet, S., Evanoff, D., 2011. The role of securitization in mortgage renegotiation. J. Financ. Econ. 102, 559-578 2011.

Agarwal, S., Amromin, G., Ben-David, I., Chomsisengphet, S., Zhang, Y., 2014. Second Liens and the Holdup Problem in Mortgage Renegotiation. National Bureau of Economic Research Working Paper 20015, March 2014.

Been, V., Jackson, H., Willis, M., 2012. Sticky seconds - the problems second liens pose to the resolution of distressed mortgages. NYU J. Law Bus. 9 (71), 71-123.

Bodfish, H.M., 1931. History of Building and Loan in the United States. United States Building and Loan League, Chicago.

Bodfish, M., Theobald, A.D., 1938. Savings and Loan Principles. Prentice-Hall, New York.

Bond, P. and Elul R., S. Garyn-Tal and D. K. Musto, "Does Junior Inherit? Refinancing and the Blocking Power of Second Mortgages, Working Paper, December 10, 2015.

Braver, H., 1936. Liquidation of Financial Institutions: A Treatise on the Law of Voluntary and Involuntary Liquidation of Banks, Trust Companies, and Building and Loan Associations. Bobbs-Merrill, Indianapolis.

Clark, H.F., Chase, F.A., 1927. Elements of the Modern Building and Loan Associations. Macmillan, New York.

Cordell, L., Dynan, K., Lehnert, A., Liang, N., Mauskopf, E., 2008. The incentives of mortgage servicers: myths and realities. Finance and Economics Discussion Series 2008-46, Divisions of Research \& Statistics and Monetary Affairs. Federal Reserve Board, Washington, D.C.
Cox, D.R., 1972. Regression models and life-tables. J. R. Stat. Soc. Ser. B (Methodol.) 34 (2), 187-220.

Effect of Insolvency upon Rights of Shareholders of Building and loan Associations, University of Pennsylvania Law Review and American Law Register, Vol. 81 No. 4 (Feb. 1933), 449-56.

Endlich, G.A., 1895. The Law of Building Associations. Frederick Linn \& Co, Jersey City.

Ewalt, J., 1962. A Business Reborn. American Savings and Loan Press, Chicago, IL.

Federal Home Loan Bank Board. Annual Report of the Federal Home Loan Bank Board. 1934-1940, Washington, D.C.: Government Printing Office.

Fishback, P., Kantor, S., Kollman, T., Haines, M., Rhode, P., Thomasson, M. Troesken, W., 2011. Information and the impact of climate and weather on mortality rates during the great depression. In: Libecap, G., Steckel, R. (Eds.), The Economics of Climate Change: Adaptations Past and Present. University of Chicago Press, Chicago, IL, pp. 131-168 2011Dataset is "Weather, Demography, Economy, and the New Deal at the County Level, 1930-1940" on the internet at https://econ.arizona.edu/faculty/webpage2_fishback_climate.asp.

Gardner, W.W., 1931. Building and Loan Liqudity. Report of the Liquidity Committee. New Jersey Building and Loan League: Bureau of Economic and Business Research of Rutgers University, New Brunswick, New Jersey 1931.

Goodman, L., 2011a, "National mortgage servicing standards and conflicts of interest," Testimony to the Subcommittee on Housing, Transportation and Community Development of the Senate Committee on Banking, Housing and Urban Affairs, May11, 2011

Goodman, L., 2011b, Examining Lien-Position Conflicts, MortgageOrb.com, June 3 2011.

Goodman, L., Ashworth, R., Landy, B., Yin, K., 2010. Second liens: how important? J. Fixed Income 20 (2), 19-30 Fall 2010.

Housing Finance Policy Center, 2015. Housing Finance at a Glance: A Monthly Update. Urban Institute, Washington, D.C. December 2015.

Imbens, G.W., Lemieux, T., 2008. Regression discontinuity designs-a guide to practice. J. Econom. 142 (2), 615-635.

Kane, E.J., 1989. The S\&L Insurance Mess: How did it Happen? Urban Institute Press, Washington, DC.

Kendall, L., The Savings and Loan Business. 1962, Prentice-Hall, Inc. Englewood Cliffs, N.J.

Lee D., C. Mayer, J. Tracy. (2012) A New Look at Second Liens. Federal Reserve Bank of New York Staff Report No. 59. August 2012.

Mayer, C., Morrison, E., Piskorski, T., 2009a. Essay: a new proposal for loan modifications. Yale J. Regul. 26 (2), 417-429.

Morgensen, G., 2010. In This Play, One Role is Enough. New York Times August 14 2010

Mortgage Bankers Association and PwC (2015). The Changing Dynamics of the Mortgage Servicing Landscape, Washington, D.C

New Jersey Building and Loan League. (1931) Report of the Liquidity Committee. Bureau of Economic and Business Research of Rutgers University: New Brunswick, New Jersey.

Piquet, H, 1931. Building and Loan Associations in New Jersey. Princeton University Press, Princeton, NJ.

Prescott, P.A., 1931. Building and Loan Procedure in New Jersey. Soney \& Sage Co. Newark.

Prevost, L., 2014. Piggyback' Loans Revisited. New York Times.

Rights of Depositors and Borrowers upon Insolvency of Building and Loan Associations (1933). The Yale Law Journal, 42:6 (Apr.), 931-941.

Rose, J, Snowden, K, 2013. The new deal and the origins of the modern american real estate loan contract. Explor. Econ. Hist. 50, 548-566 (2013).

Rose, J, 2014. The prolonged resolution of troubled real estate lenders during the 1930s. In: Eugene, N.W., Snowden, K., Fishback, P. (Eds.), Housing and Mortgage Markets in Historical Perspective, edited by. University of Chicago Press.

Snowden, K., 2003. The transition from building and loan to savings and loan. In: Engerman, S., Hoffman, P., Rosenthal, J., Sokoloff, K. (Eds.), Finance, Inter mediaries and Economic Development. Cambridge University Press, Cambridge, pp. 157-206. 
S. Fleitas et al./J. Finan. Intermediation 000 (2017) 1-17

Snowden, K., 2006. Housing. In: Carter, S., et al. (Eds.), Historical Statistics of the United States, Millennial Edition, edited by. Cambridge University Press, New York.

Snowden, K., 2010. The anatomy of a residential mortgage crisis: a look back to the 1930 s. In: Lawrence, E.M., Wilmarth, A.E. (Eds.), The Panic of 2008: Causes, consequences and proposals for reform, edited by. Edward Elgar, Northampton, MA.

Sundheim, J.H., 1922. The Law of Building and Loan Associations (second ed.). Smith-Edwards Company, Philadelphia.
U.S. Bureau of the Census, 1975. Historical Statistics of the United States: Colonial Times to 1970. Government Printing Office, Washington, DC.

U.S. House of Representatives, (1932). Report No. 98 to accompany House Resolution 374, January 15, 1932. $72^{\text {nd }}$ Congress, Session 1. Washington, DC: Government Printing Office.

Wheelock, D.C., 2008. The federal response to home mortgage distress: lessons from the great depression. Federal Reserve Bank of St. Louis Review May/June (Part 1), 133-148. 